\title{
Erken Çocukluk ve Çocukluk Dönemini Değerlendiren Motor Gelişim Ölçeklerinin İncelenmesi
}

\author{
Investigation of Motor Development Scales Evaluating Early Childhood \\ and Childhood Period
}

\author{
Özlem KANBİR* \\ Özlem AKKOÇ*艹 \\ Sena KIRLANGIÇ ${ }^{* * *}$ \\ Ayşe Oya ERKUT ${ }^{* * * *}$ (iD
}

Öz

$\mathrm{Bu}$ araştırmada erken çocukluk ve çocukluk çağında, çocukların motor gelişimini değerlendirmek için yapılan ulusal ve uluslararası 'Motor Değerlendirme Ölçekleri’nin incelenmesi amaçlanmıştır. Çocuklarda motor gelişim refleks hareketlerle başlar ve bu süreç vücudun birçok kısmının dahil edildiği daha koordineli ve amaca yönelik hareketler bütünü olarak devam eder. Fiziksel büyüme ve sinir sisteminin gelişmesine bağlı olarak normal bir büyüme seyri gösteren her çocuk belli başlı hareket becerilerini planlama ve uygulama konusunda başarılı olur. Bu hareket becerilerini kazanmada belli motor gelişim dönemleri vardır. Yapılması beklenen hareketlerden lokomotor hareketler; bireyin bedeni sabit bir yerden başka bir yere taşıması, manipülatif hareketler; bireyin kullanacağı nesne ile yapmış olduğu hareketler ve dengeleme hareketler ile bireyin belirli bir süre için denge hareketlerini içermektedir. Araştırmaya dahil edilen 'Motor Gelişim Ölçekleri' bu alanda yapılan çalışmalarda yaygın olarak kullanılan ölçekler arasından değerlendirmeye dahil edilmiştir. Araştırmanın yöntemi 'geleneksel derleme modeline' göre tasarlanmıştır. Araştırmaya konu olan motor gelişim ölçekleri; TGMD-2 (Test of Gross Motor-2), CHAMPS Motor Beceriler Protokolü, BOT-2 (Bruininks - Oseretsky Motor Yeterlilik Testi2), Çocuk Beden Koordinasyon Testi ( Körperkoordinations Test Für Kinder, KTK), Çocuk Movement ABC-2 (Çocuk Hareket Değerlendirme Bataryasi), BüKBÖT (Büyük Kas Beceri Ölçme Testi) olarak toplam 7 adet test değerlendirilmiş olup, geçerlik ve güvenirlik puanları, testlerin kullanım amaçları, yaş grupları, güçlü ve zayıf yönleri gibi değerlendirmeleri yapılmış ve incelenmiştir.

Anahtar Kelimeler: Motor gelişim, motor değerlendirme ölçekleri, kaba motor, ince motor

* Doktora öğrencisi, Marmara Üniversitesi Eğitim Bilimleri Enstitüsü, İstanbul, ozlemkanbir@hotmail.com, ORCID: 0000-0001-6272-3720

** Doktora öğrencisi, Marmara Üniversitesi Eğitim Bilimleri Enstitüsü, İstanbul, akkocozlem@gmail.com, ORCID: 00000003-4116-0628

*** Doktora öğrencisi, Marmara Üniversitesi Eğitim Bilimleri Enstitüsü, İstanbul, kirlangicsena@gmail.com, ORCID: 00000003-1002-7808

**** Prof. Dr., Marmara Üniversitesi, Spor Bilimleri Fakültesi, İstanbul, oerkut@marmara.edu.tr, ORCID: 0000-0002-1469-9970 


\begin{abstract}
In this study, it was aimed to examine the national and international 'Motor Assesment Scales' to evaluate the motor development of children in early childhood and childhood. Motor development in children begins with reflex movements, and this process continues as a set of more coordinated and purposeful movements in which many parts of the body are involved. Every child who shows a normal growth course depending on the physical growth and the development of the nervous system is successful in planning and performing certain movement skills. There are certain motor development periods in acquiring these movement skills. Locomotor movements from the expected movements; moving the body from one fixed place to another, manipulative movements; It includes the movements and balancing movements of the individual with the object to be used and the balance movements of the individual for a certain period of time. The "Motor Development Scales" included in the study were evaluated among the most common scales in studies in this field. The study method was designed according to the "traditional compilation" model. Motor development scales that are the subject of research; TGMD-2 (Test of Gross Motor-2), CHAMPS Motor Skills Protocol, BOT-2 (Bruininks - Oseretsky Motor Proficiency Test2), Child Body Coordination Test ( Körperkoordinations Test Für Kinder, KTK), Child Movement ABC-2 (Child Movement Evaluation Battery), BuKBOT (Gross Muscle Ability Assessment Test), a total of 7 tests were evaluated and evaluations such as validity and reliability scores, intended use of the tests, age groups, strengths and weaknesses were identified and investigated.
\end{abstract}

Keywords: Motor development, motor assessment scales, gross motor, fine motor

\title{
GİRIŞ
}

Psikomotor gelişim, bireyin yaşamının ilk zamanları ile başlayıp dönemsel yeterliği ifade eder. Fiziksel gelişimi, bedensel gelişim ile birlikte oluşturan ve tamamlayan bir gelişim alanı olarak değerlendirilmektedir. Motor gelişim ile genellikle aynı anlamda kullanılan psikomotor gelişim, motor gelişimden farklı olarak anne karnında başlayıp ömür boyu süren zamansal dönemi ifade etmektedir. Motor gelişim ise yaş, dönem ve evrelerinin gerektirdiği hareket gelişimi olarak değerlendirilmektedir (Topkaya, 2015).

Bebeklik döneminde çocuğun gelişiminden motor gelişim olarak bahsedilir (Berk, 2003). Daha sonraları çocuk bir yere ulaşabildiğinde, kavrayabildiğinde, yürüyebildiğinde daha karmaşık hareket becerilerinin geliştirilmesinde anne-babaların ilgisi azalır. Çocukların bilişsel, sosyal ve duygusal gelişimine daha fazla önem verilir. Motor gelişimleri ise sadece işlev bozuklukları veya verimsiz hareket davranışı ortaya çıktığında dikkate alınır (Davies, 2003).

Çocuğun motor gelişimi, refleksif hareketler ile başlayan ve ilkel hareketlere ve ardından temel hareketlere evrilen ve daha karmaşı motor becerilerin öğrenilmesi ile devam eden bir süreçtir.

Normal gelişim düzeyine sahip çocuklar, fiziksel olgunlaşmaları ve merkezi sinir sistemlerinin gelişimlerine bağlı olarak hareket becerilerini kazanırlar. Bu becerileri kazanırken çocuklar belirli bazı dönemlerden geçerler. Örneğin; emekleme, yürüme, koşma vb. Bu beceriler birbirini takip eden ve temel spor hareketlerinin ilk basamaklarını oluşturan hareketlerdir (Gallahue, Ozmun, ve Goodway, 2006). 
Çocukların tüm gelişim alanlarının değerlendirilmesi, gelişimlerinin desteklenmesi açısından önem taşımaktadır. Bu değerlendirmeler, gelişim alanlarının dengeli olması, bir gelişim alanının başka bir gelişim alanından eksik veya geride tutulmaması için önemlidir (Kılıç, Uyanık ve Sarı, 2017). Bunlara ilave olarak çocukların bütüncül gelişimleri üzerinde etkisi ve önemi yapılan araştırmalarla vurgulanan motor gelişimin desteklemesine yönelik hareket eğitimi programlarının hazırlanması için de bu değerlendirmeler önem taşır. Çocukların motor gelişim düzeylerinin belirlenip, planlı ve programlı beceri kazanımına yönelik hareket eğitimi içeriğinin oluşturulması, çocukların hareket becerilerinin ve kapasitelerinin geliştirilmesi açısından önemli bir konudur.

Çocukların gelişimlerinin erken yaşlarda değerlendirilmesi, motor gelişimleri ile ilgili olan eksikliklerin fark edilmesine ve motor yeterliklerin gelişmesi için uygun programların oluşturulmasına yardımcı olur (Burton ve Miller, 1998; Wiart ve Darah, 2001). Bu gereklilikten yola çıkarak araştırmacılar, çocukların motor gelişimlerinin değerlendirilmesi için ölçme değerlendirme araçları hazırlamışlardır. Erken çocuklukta hareket performansını değerlendirmek ve okul öncesi, okul çağı ve gençlerin motor gelişimlerini değerlendirmek ve yorumlamak adına yapılan ve uygulanan birçok test hazırlanmıştır (Barnett ve Peters, 2004; Simons, 2004; Vallaey ve Vandroemme, 2001; Wiart ve Darrah, 2001). Bu testlerden hangisinin kullanılacağına karar vermek için, testin güvenirliği ve geçerliğine ek olarak testin amacına ve çocuğun özelliklerine bakılmalıdır. Bu testlerin çoğu belirli bir hedef gruba yöneliktir ve dolayısıyla buna uygun bir içeriğe sahiptir.

Hareket değerlendirmesi için hazırlanan testler norm veya kriter referanslıdır. Norm referanslı bir test, çocuğun performansını normatif bir grubun performansıyla karşılaştırır ve çocuğun hareket becerisi yeterliğini ölçer. Kriter referanslı bir test ise, çocuğun performansını önceden belirlenmiş kriterlerle karşılaştırır. Aynı zamanda kriter referanslı bir test, hareket becerisi öğesini gerçekleştirmek için gereken hareketlerin niteliksel yönlerini dikkate alır (Cools ve diğ.,, 2009). Barnett ve Peters (2004), Tieman ve diğ., (2005), Cools ve diğ., (2009), Yoon ve diğ., (2006), Wiart ve Darrah (2001) araştırmalarında hareket performansı testlerini incelemişler ve hareket performansı değerlendirmelerinin potansiyel faydasını değerlendirmişlerdir.

Ülkemizde kullanılmakta olan ölçme araçlarının birçoğunun yurt dışında geliştirilen ve Türkçeye uyarlaması yapılarak geçerlik ve güvenirlik çalışması yapılan testler olduğu görülmektedir. Araştırmamızda okul öncesi, okul çağı ve gençlerin motor gelişimlerini değerlendirmek ve yorumlamak adına yapılacak çalışmalarda araştırmacıların hangi testi uygulayacaklarını seçmeleri açısından kolaylık sağlaması, motor gelişim testlerinin kullanıcılara avantaj ve dezavantajlarının açılanması ve erken çocukluk ve çocukluk çağında, çocukların motor gelişimini değerlendirmek için yapılan ulusal ve uluslararası 'Motor Değerlendirme Ölçekleri' nin incelenmesi amaçlanmıştır. İçerik ve test yönetimi, geçerlik, güvenirlik ve normatif veriler dahil olmak üzere değerlendirme araçlarının farklı yönleri açıklanmıştır. Araştırmamız aşağıdaki testlerin değerlendirilmesini içerir:

- Test of Gross Motor Development (TGMD)

- CHAMPS Motor Beceriler Protokolü

- Bruininks-Oseretsky Motor Yeterlik Testi-2 (BOT-2) 
- Peabody Motor Gelişim Ölçeği-2

- Çocuk Beden Koordinasyon Testi (Körperkoordinations Test Für Kinder [KTK])

- Çocuk Hareket Değerlendirme Bataryası (Movement ABC - 2)

-Büyük Kas Becerilerini Ölçme Testi (BüKBÖT)

Motor gelişim ölçme ve değerlendirme testleri bazı uygulamalarda farklılık gösterse de, temel kavramların tümü benzerlik göstermektedir.

\section{Test of Gross Motor Development (TGMD)}

Test of Gross Motor Development (TGMD) Ulrich (1985) tarafından 3 ile 10 yaş arasındaki çocukların motor davranışlarını değerlendirmek amacıyla geliştirilmiştir. Test of Gross Motor Development (TGMD) testi iki alt testten oluşmaktadır. Bu testin hareket alt testi 7 adet beceriyi (koşma, gallop, sekme, tek ayak üzerinde sıçrama, sıçrayarak atlama, uzun atlama, yana kayma) ölçerken, nesne kontrol alt testi 5 beceriyi (duran topa vurma, top sektirme, yakalama, topa ayakla vurma, el üstünden top firlatma) ölçmektedir. Testin norm verisi 8 eyalette yaşayan 909 adet bireyden toplanmıştır. Veriler, fiziksel eğiticiler, sınıf öğretmenleri, ders öğretmenleri ve üniversitelerdeki fakülte öğretim elemanları tarafından toplanmıştır. Normatif veriler cinsiyet, ırk ve coğrafi bölge değişkenleri temel alınarak toplanmıştır. Lokomotor alt test için iç tutarlılık güvenirlik katsayıları .79 ile .90 arasindadır ve ortalaması .85 'dir. Nesne kontrol katsayıları ise .67 ile .93 arasındadır ve ortalamas1 .78'dir (Tepeli, 2007).

Test of Gross Motor Development testi Ulrich tarafindan (2000) yilında Amerika normlarına göre geliştirilmiştir. Testin yeniden düzenlenmiş ikinci sürümü 2000 yllında TGMD-2 şeklinde yayınlanmıştır. Dinamik sistem teorisini temel alarak oluşturulan TGMD-2'de değerlendirme sadece "ne sürede koştu", "ne kadar uzağa attı" gibi sonuç bilgisine dayanmaz. Hareket uygulaması sırasında çocuğun gövde, kol ve bacaklarını koordineli kullanıp kullanmadığının değerlendirilebildiği hareket analizine dayalı bir test olması nedeniyle araştırmacılar tarafından tercih edilmektedir. Ancak her bir beceride gövdenin, kol ve bacakların duruş ve hareketlerinin ayrı ayrı puanlanması gerektiğinden testin uygulaması ve puanlaması uzmanlık gerektirmektedir (Kerkez, 2013). 2000 yılında revize edilen Test of Gross Motor Development ölçme aracı; Tepeli (2007) tarafından 'Büyük Kas Becerilerini Ölçme Testi (BüKBÖT) olarak Türkçeye uyarlanmıştır. Lokomotor ve nesne kontrol olmak üzere 2 alt testten oluşan ölçme aracı toplamda 12 büyük kas becerisini ölçmektedir. Büyük Kas Becerilerini Ölçme Testinin geçerlik güvenirlik çalışmaları kapsamında madde analizi için geçerliği test etmeye yönelik madde analizi ve yapı geçerliği sınamaları yapılmıştır. Güvenirlik çalışmasına yönelik olarak gözlemciler arası tutarlık, testin aralıklı tekrar ve iç tutarlık katsayıları; lokomotor beceri alt testi için iç tutarlık katsayıları yaşlara göre; 3 yaş için .82, 4 ve 5 yaş için .78; 6 yaş için .76'dır. Nesne kontrol beceri alt testi için iç tutarlık katsayıları yaşlara göre; 3 yaş için .74, 4 yaş için .72, 5 yaş için .65, 6 yaş için .77’dir. Büyük Kas Becerileri Ölçme Testi toplam puanına ilişkin kat sayılar; 3 yaş için .86, 4 yaş için .83, 5 yaş için .78 ve 6 yaş için .85 olarak verilmiştir (Tepeli, 2007). 


\section{CHAMPS Motor Beceriler Protokolü}

CHAMPS Motor Beceriler Protokolü (CHAMPS Motor Skills Protocol - CMSP) 2009 yılında, South Carolina Üniversitesi'nden Harriet G. Williams, Karin A. Pfeiffer, Marsha Dowda, Chevy Jeter, Shaverra Jones ve Russel R. Pate’in, alana özgü yeni bir motor ölçeği kazandırmak amacıyla ortaya çıkarılan bir protokoldür. CHAMPS Motor Beceriler Protokolü’nün ortaya çıkma aşamasında, alanında uzman araştırmacılar Movement Assessment Battery for Children (MABC), Peabody Developmental Motor Scales (PDMS) ve Test of Gross Motor Development 2nd Edition (TGMD2) ölçme araçlarını incelemiş, ve TGMD-2'nin 3-5 yaş arası çocukların motor becerilerini ölçme noktasında çalışmalarına temel oluşturabilecek en mantıklı ve uygun ölçme aracı olduğuna karar vermişlerdir. Bu gerekçelerden hareketle CMSP’nin geliştirilmesinde TGMD-2 araştırmacıları yol gösterici olmuştur.

CHAMPS Motor Beceriler Protokolü, iki alt boyuttan ve toplam 70 maddeden oluşmaktadır. Bu alt boyutlar:

1. Yer Değiştirme (Lokomotor) Alt Boyutu

a. Koşma (6 madde)

b. Durarak uzun atlama (5 madde)

c. Kayma adımı ( 7 madde)

d. Gallop (7 madde)

e. Siçrama ( 3 madde)

f. Sekme ( 6 madde)

h. Nesne Kontrolü Alt Boyutu

a. Baş üstü atış ( 6 madde)

b. Aşağıdan yuvarlanma (6 madde)

c. Ayakla vurma ( 7 madde)

d. Yakalama ( 5 madde)

e. Sabit duran topa sopa ile vurma (7 madde)

f. $\quad$ Top sektirme ( 5 madde)

CHAMPS Motor Beceriler Protokolü’nün geliştirilmesi ve geçerlik güvenirlik çalışması için 22 okul öncesi kurumdan, 3-5 yaşları arasında 297 çocukla çalışılmıştır. CHAMPS Motor Beceriler Protokolü’nün geçerlik çalışmasında TGMD-2 ölçüm aracı kullanılmış ve ölçümler her iki ölçme aracıyla da yapılarak her iki ölçüm aracının karşılaştırılması yapılmıştır. Testlerin karşılaştırılmasında ise Pearson Korelasyon analizi kullanılmıştır. Yapılan analiz sonuçlarına göre ise CMSP ve TGMD-2 ölçeklerinin lokomotor alt ölçeklerinin .98, nesne kontrolü alt ölçeklerinin .97 ve toplam puanların .98 geçerlik puanı aldıkları tespit edilmiştir. 
Yapılan çalışmalar çocuklarla birebir yapılmış olup bir çocuğun ölçümünün tamamlanması 2530 dakika sürmüştür. Ölçüm yapılma aşamasında hareketler önceden çocuklara gösterilip daha sonradan onları yapmaları için çocuklara iki deneme hakkı verilmiştir. Çocukların her denemeleri de ölçüm formlarına kaydedilmiştir.

CHAMPS Motor Beceriler Protokolü’nün güvenirlik çalışmasında ise iki gözlemci 22 okuldan 50 çocuk ile çalışmış ve her iki gözlemcinin puanları karşılaştırılmıştır. Bu noktada ise gözlemciler arası uyum puanları lokomotor alt ölçeğinde .99 , nesne kontrolü alt ölçeğinde .98 ve toplamda .94 olarak belirlenmiştir (Williams ve diğ.,, 2009). CHAMPS Motor Beceriler Protokolü’nün 4-5 yaş yönelik Türkçeye uyarlama çalışması Kılıç (2017) tarafından yapılmıştır. Çalışmaya özel anaokulları, bağımsız anaokulları ve okul bünyesinde bulunan anasınıflarına devam eden 4 ve 5 yaşlarında toplam 336 çocuk katılmıştır. İç tutarlık çalışması kapsamında ölçme aracının alt boyutlarındaki her becerinin güvenirlik değerlerini ve ölçme aracının genel iç tutarlık değerini belirlemek üzere analizler yapılmış ve ölçme aracının genel iç tutarlılık değeri .77 olarak hesaplanmıștır (Kılıç, 2017).

\section{Bruininks-Oseretsky Motor Yeterlik Testi-2 (BOT-2)}

Bruininks Oseretsky Motor Yeterlilik Testi Bruininks (1978) tarafından 4,5-14,5 yaş grubundaki çocukların motor yeterliklerini ölçmek amacıyla geliştirilmiştir (Mülazımoğlu ve Gürsoy, 2012). Motor yeterlik testi yaşanılan ya da yaşanması muhtemel olan motor gerilikleri belirlemede önemli bir araçtır (Bruininks ve Bruininks, 1977). Bruininks-Oseretsky Motor Yeterlik Testi 2005 yılında güncellenerek 46 maddeden 14 madde çıkarılıp 21 madde eklenerek Bruininks-Oseretsky Test-2 halini almıştır ve 4-21 yaş arası çocuklara uygulanabilir hale gelmiştir (Köse, 2018). BOT-2 4 motor alana ve 8 alt teste ayrılmıştır. Motor alanlar; ince motor kontrol (ince motor hassasiyeti-7 madde, ince motor entegrasyonu- 8 madde), el koordinasyonu (el becerisi-5 madde, üst ekstremite koordinasyonu-7 madde), vücut koordinasyonu (iki yönlü koordinasyon-7 madde, denge-9 madde), kuvvet ve çeviklik (hareket hızı ve çeviklik-5 madde, kuvvet-5 madde) ile toplam 53 maddeden oluşan bu test kaba ve ince motor becerilerini detaylı bir şekilde ölçmektedir (Karakaş, 2018). Testin norm verisini Amerika'da 239 eyaletten 1520 çocuk oluşturmaktadır (Cools ve diğ.,, 2009). 53 maddelik tüm test materyallerinin bir çocuk için uygulama süresi 40-60 dk arasında değişmektedir ve bu testten alınabilecek en yüksek puan 320'dir (Bruininks, 2005). Ortalama alt test korelasyonları .69 ile .70 arasında değişmektedir. Ortalama bileşik korelasyon katsayıları .77 ile .80 arasında değişmektedir. Alt test güvenirliği .70 ile .80 arasında değişmektedir (Cools ve diğ.,, 2009).

Bu testin 53 maddesinin içinden temsil edebilecek şekilde 14 maddelik kısa bir form oluşturulmuştur (BOT-2 Short Form) (Deitz, Kartin, ve Kopp, 2007). 2010 yılında güncellenen haliyle madde sayısı 14'ten 12'ye düşürülmüş ve bazı maddeler çıkarılıp bazı maddeler eklenmiştir. Bu testin ise uygulanma süresi 15-20 dk arasında değişmektedir. Alınabilecek en yüksek puan ise 72'dir (Bruininks ve Oseretsky, 2010). BOT-2 kısa formunun Türkçe Uyarlaması ve Özgül öğrenme güçlügü olan çocuklarda geçerlik ve güvenirlik çalışması Köse (2018) tarafından yapılmıştır. Çalışmaya özgül 
öğrenme güçlüğü tanısı konulan 6-14 yaş arası 137 çocuk ve tanı almayan (sağlıklı) 50 çocuk dahil edilmiştir. BOT2-KF’nin geçerliği, yapı geçerliği yöntemi ile, güvenirliği ise; iç tutarlık, test-tekrar test ve uygulayıcılar arası güvenirlik yöntemleri kullanılarak incelenmiştir. Cronbach $\alpha$ katsayısı .78 olarak bulunmuştur. BOT 2-KF’nin ince motor doğruluk alt testi (ICC .57) ve el becerisi alt testi (ICC .74) orta derecede güvenilir, bu iki alt test dişında kalan diğer alt testler iyi derecede (ICC >.8) güvenilir bulunmuştur (Köse, 2018).

\section{Peabody Motor Gelişim Ölçeği-2}

Peabody Motor Gelişim Ölçeği ilk olarak 1983 yllında Folio ve Fewel tarafından geliştirilmiştir (Folio ve Fewell, 1983). 2000 yılında ise aynı yazarlar tarafından ikinci baskısı yayınlanmıştır. Peabody Motor Gelişim Ölçeği-2'nin geliştirilmesinde norm verileri Amerika Birleşik Devletleri’nde yaşayan 2003 çocuktan toplanmıştır (Folio ve Fewell, 2000). Doğumdan 71 aya kadar sağlıklı gelişim gösteren çocukların ya da özel gereksinimi olan çocukların kaba ve ince motor gelişim düzeylerini ayrıntılı maddelerle ölçmek için geliştirilen bu ölçeğin kaba motor alt boyutları; refleksler, denge, yer değisstirme, nesne yönlendirme olmak üzere 4 boyuttan oluşmaktadır. İnce motor boyutları; kavrama, el-göz koordinasyonu olmak üzere 2 boyuttan oluşmaktadır (Taştepe ve Akyol, 2019). Ölçek toplamda 249 maddeden oluşmaktadır ve ölçeğin tamamının uygulanması 45-60 dk sürmektedir. Kaba ya da ince motor becerileri içeren alt boyutlar 20-30 dk içinde uygulanabilmektedir. Beş alt boyutta ölçeğe hangi maddeden başlanacağını çocuğun yaşı belirlemektedir. Kalan refleksler alt boyutu ise 12 aydan küçük çocuklara uygulanmaktadır ve her zaman ilk madde ile başlanmaktadır. Ölçeğin alt boyutlarının iç tutarlık katsayıları .89 ve .96 arasında değişmektedir. Ölçeğin toplamına yönelik iç tutarlık kat sayıs1 .97'dir (Folio ve Fewell, 2000). Peabody Motor Gelişim Ölçeği-2 'nin 36-47 aylık Türk çocukları için geçerlik ve güvenirlik çalışması Taştepe ve Akyol tarafından (2019) yılında yapılmıştır. Çalışmaya 2016-2017 eğitim öğretim yılında Ankara ili merkez ilçelerindeki Milli Eğitim Müdürlüğüne bağlı resmi anaokullarına devam eden 36-47 aylık toplam 191 çocuk katılmıştır (Taştepe, 2018). PMGÖ-2'nin uyarlama çalışmasında; uzman görüşlerine dayalı olarak kapsam geçerliği, yapı geçerliğine kanıt toplamak amacıyla doğrulayıcı faktör analizi (DFA), güvenirliği belirlemeye yönelik iç tutarlılık için Cr-a katsayısı ve güvenirliğe kanıtı artırmak için test-tekrar test katsayısı incelenmiştir. PMGÖ-2'nin kapsam geçerliğinin istatistiksel olarak anlamlı olduğu sonucuna ulaşılmıştır. DFA sonucunda, PMGÖ-2'nin kaba ve ince motor boyutları ve bu boyutların alt boyutları tarafından doğrulandığı belirlenmiştir. Ayrıca gizil değişken olan kaba motor boyutu denge, yer değiştirme ve nesne yönlendirme alt boyutları tarafından; diğer bir gizil değişken olan ince motor boyutu kavrama ve el-göz koordinasyonu alt boyutları tarafından anlamlı olarak yordanmaktadır. Cr- $\alpha$ iç tutarlık katsayısı ile test-tekrar test güvenirlik kat sayısının boyutlar/alt boyutlar için .70 sınır değerinin üzerinde olduğu tespit edilmiştir. Elde edilen bulgular, PMGÖ-2’nin Türk çocukları için geçerli ve güvenilir bir ölçme aracı olarak kullanılabileceğini göstermektedir (Taştepe ve Akyol, 2019). 


\section{Çocuk Beden Koordinasyon Testi (Körperkoordinations Test Für Kinder [KTK])}

Çocuk Beden Koordinasyon Testi (KTK) Kiphard ve Schilling (1974) tarafından geliştirilmiş ve 2007 yılında revize edilip modernizasyonu sağlanarak 5-14 yaş arasındaki çocukların koordinasyon ve hareket yetkinliklerini değerlendirmek amacıyla tasarlanmıştır (Kiphard ve Schilling, 2007). Okul çağı çocuklarında basit hareket bölümlerinden yüksek düzeydeki hareket davranışlarına kadar sahip olan veya bu becerilerde problem yasayan tüm çocuklarda uygulanabilir. Bu test türü dezavantajlı olan çocukların alışık olmadıkları bir testteki davranış durumları ile karşı karşıya kaldıklarından dolayı pasif olarak yıllardır kendilerinde bulunan motor eksikliklerin tespiti için de önemli bir test durumundadır. Bu nedenle, Çocuk Beden Koordinasyon Testi çocukluk döneminde uygulanmakta olan en önemli testlerden biridir (Fransen ve diğ.,, 2014; Hardman ve diğ.,, 2017; Kiphard ve Schiling, 2007; Livonen, Saakslahti ve Laukkanen, 2016). Çocuklar Beden Koordinasyon Testi motor becerileri değerlendirmek acısından oldukça güvenilir $(r=.85)$ ve geçerli $(r=.60-.80)$ bir ölçme aracıdır (Kiphard ve Schilling, 2000; Livonen, Saakslahti ve Laukkanen, 2016). Geriye dengeleme, tek ayak sekme, yanlara sıçrama ve yanlara adımlama (platformla) gibi 4 fiziksel testten oluşmaktadır. Her bir çocuk için uygulama süresi ortalama 15 dakikadır. Testin değerlendirilmesi "yetersiz motor koordinasyon" (MK<56), "şiddetli motor yetersizlik" (MK 56-70), "orta dereceli motor yetersizlik" (MK 71-85), "normal” (MK 86-115), “iyi” (MK 116-130) ve “çok iyi” (MK 131-145+) kategorilerinden oluşmaktadır. Alt testlerden alınan ham puanların ortalaması ile yaş ve cinsiyet değerlendirilmesi yapılarak genel motor koordinasyon puanı tespit edilmektedir. KTK çocukların motor koordinasyon düzeyleri ile birlikte genel olarak psikomotor, sosyal, psikolojik ve sağlıklı yaşam düzeylerini değerlendirmeyi amaçlayan araştırmalarda da kullanılmaktadır. Çocuk Beden Koordinasyon Testi 'nin Ortaokul Grubu Türk Çocukları İçin Geçerlilik ve Güvenirlik Çalışması Özkara ve Kalkavan tarafından (2018) yapılmıştır. Çalışmaya Trabzon ili Akçaabat ilçesinde yer alan 202 (86 kız, 116 erkek; $\overline{\mathbf{x}}=12,27$ yaş) ortaokul öğrencisi katılmıştır. Bu çalışmanın sonuçlarına, kapsam geçerliği analizinde elde edilen kapsam geçerliği indeksi (KGİ=.95), yapı geçerliği analizleriyle elde edilen eş zaman geçerliği $(r=.95)$ ve doğrulayıcı faktör analizi $\left(\mathrm{sd}=2, \chi^{2}=1,84 ; \mathrm{p}<0,01\right.$; GFI $=.99$, AGFI= .97, $\mathrm{CFI}=1, \mathrm{RMSEA}=0,01, \mathrm{IFI}=1$ ) vasıtasıyla ulaşılmıştır. KTK testinin güvenirliğine ilişkin sonuçlar incelendiğinde, test tekrar test $(\mathrm{r}=.90)$ ve ayırt edicilik indeksi $(\mathrm{t}(109)=-31,23, \mathrm{p}<0,01)$ analizleri güvenirlik varsayımlarının sağlanması açısından değerlendirilmiştir (Özkara ve Kalkavan, 2018).

\section{Çocuk Hareket Değerlendirme Bataryası (Movement ABC - 2)}

İlk geliştirildiği zaman Motor Bozukluk Testi - Handerson Revizyonu (Test of Motor Impairment - Handerson Revision) olarak adlandırılan Çocuk Hareket Değerlendirme Bataryası - Hareketin ABC'si, çocukların motor bozukluk düzeyini ve gelişimdeki gecikmeyi belirlemek üzere geliştirilmiştir. 4-14 yaş grubu çocukların nitel ve nicel büyük ve küçük kas motor beceri normlarını içermektedir. Test dört ayrı yaş grubuna bölünmüş olup, 32 maddeden oluşmaktadır. Her yaş grubu üç kategoride hareket becerilerini ölçen 8 ayrı test öğesi ile el becerileri, materyal olarak topun kullanıldığı beceriler ve denge becerilerini içermektedir. Testin uygulama süresi 20-30 dakika sürmektedir. Testin toplam puanı çocuğun performansını ifade eder. 6 puanlık derecelendirme 
puanı vardır, en iyi derece 0 en zayıf derece ise 5 puan derecelendirme ölçeğine göre derecelendirilir. Testin en önemli avantajlarından birisi çeşitli Avrupa ülkelerinde kullanılabilirliği ve yerel örnek verilerle karşılaştırmaya dayanan kültürler arası geçerliği ve kısa süre içerisinde geniş örnek taramalarına olanak sağlayan uygulama açısından basit bir test olmasıdır (Smits - Engelsman, 1998; Petermann,2008; Soppelsa ve Albert, 2004). Çocuğun geniş bir beceri yelpazesinde güçlü ve zayıf yönlerini ölçen BOT-MP (Bruininks Oseretsky Test of Motor Proficiency) gibi diğer hareket becerisi testlerinden farklı olarak, Hareket-ABC belirli bir yaş aralığındaki hareket becerileriyle sinırlıdır. Hareket-ABC, ürün odaklı bir testtir ve bir normu ifade eder. Gözden geçirilmiş versiyonda nitel gözlemler eklenmiştir. Ancak, puan üzerinde bir etkisi yoktur ve çocukların bir hareketi yerine getirme durumunda karşılaştıkları zorlukları belirtmeleri amaçlanır. Hareket-ABC testi revize edilerek Hareket ABC-2 olarak yenilenmiştir ve yaş aralığı olarak 5-12 yaş arasındaki çocukların okulda ve evde karşılaştıkları günlük görevleri nasıl yönettiklerine odaklanmıştır. Testin içeriğinde hareketi etkileyebilecek doğrudan veya dolaylı faktörler hakkında bilgi sağlayan motor ve motor olmayan bileşenler bulunur. Test entegre motor becerilerin gelişimindeki problemler için bir tarama aracı olarak kullanılır. Test özellikle motor kontrolün işlevsel entegrasyonundaki sorunları veya okul öncesi ve ilkokul yıllarının ilk yıllarında ilk kez ortaya çıkan sorunları keşfetmek için önemli bir ölçektir (Rosenbaum ve diğ.,, 2004). Burton ve Miller (1998) testi motor becerilerin erken dönemlerini, motor hareket ve özelleşmiş hareket becerilerinin değerlendirilmesi için uygun bir araç olarak belirtmiştir. Kültürler arası geçerlik birçok çalışma ile desteklenmiş ve Hareket-ABC testi birkaç dile çevrilmiştir (örneğin: Çince, Hollandaca, Danca, İsveççe, İtalyanca ve Japonca) (Barnet ve Peters,2004; Chow ve diğ.,, 2001; Chow ve diğ.,, 2006). Revize edilmiş versiyonda:

a. Test üç bileşene bölünmüştür; standart bir test, bir kontrol listesi ve hareket güçlüğü çeken çocuklara yönelik müdahaleye yönelik bir yaklaşımı gerçekleştirilmiş̧tir,

b. Yaş aralığ 3-16 olarak değiştirilmiş ve yaş aralıkları 3 ile 6 yaş grubu, 7 ile 10 yaş grubu, 11 ile 16 yaş grubu olarak belirlenmiştir,

c. Uygulamada kullanılacak olan materyaller aşırı aşınmaların ortadan kalkması için tahtadan plastiğe dönüştürülmüştür,

d. Uygulamada çocukların yapmakla yükümlü olduğu hareketler yeni hareketlerle değiştirilmiştir (bisiklet kullanma yerine çizim yapma gibi),

e. Test yönetimi ve puanlamadaki belirsizliği azaltmak için test talimatları daha net ve anlaşılır olarak değiştirilmiştir,

f. Güncellenen normatif veriler; çalışmaya Kasım 2005 ile Temmuz 2006 arasında 1172 çocuk katılmıştır (yaş aralığ 1 (3-6 y) $n=431$; yaş aralığı 2 (7-10 y) $n=333$ ve yaş aralığı 3 (11-16 y) $\mathrm{n}=408)$,

g. Tüm veriler İngiltere ve Kuzey İrlanda’da toplanmıştır ve örnek coğrafi bölge, nüfus yoğunluğu, sosyal sınıf ve ırk veya etnik köken için katmanlara ayrılmıştır. 


\section{Büyük Kas Becerilerini Ölçme Testi (BüKBÖT)}

Büyük Kas Beceri Ölçme Testi (BüKBÖT), Dale A. Ulrich (2000) tarafından Amerikan norm değerlerine göre standardize edilen 'Test of Gross Motor Development - Secon Edition (TGMD-2)'e dayanılarak geliştirilmiştir. Bu test 3-10 yaş çocukların büyük kas becerilerini belirleyebilmek için kullanılır. Testin oluşturulmasında Türkiye’nin 7 bölgesinden tesadüfi olarak seçilen 14 şehirdeki 310 yaş arası 1600 çocuk katılım sağlamıştır. Büyük Kas Becerilerini Ölçme Testi lokomotor ve nesne olarak iki alt ölçekten meydana gelmiştir. Lokomotor alt testinde; koşu, gallop, tek ayak üzerinde sıçrama, sıçrayarak atlama, uzun atlama, yana kayma olmak üzere 6 beceri vardır. Nesne kontrol alt testinde; duran topa vurma, top sektirme, topu yakalama, topa ayakla vurma, el üstünden top firlatma, el altından top yuvarlama olmak üzere 6 beceri vardır. Alt testlerde yer alan her bir motor beceri, performans kriteri olarak verilen 3 ile 5 arasında değişen davranış ölçümlerini içermektedir. Bu davranışlar becerinin bir kısmını temsil etmektedir. Nesne kontrol alt testinde 24, lokomotor alt testinde de 24 motor beceri kriteri yer almaktadır. Çocuklara uygulanırken her çocuk için 2 deneme hakkı verilir ve iki denemenin puanları kayıt alınır. Çocuk bir davranış bölümünü doğru yaparsa 1 puan, yanlış yaparsa 0 puan ile puanlandırılır. Araştırıcı iki denemenin her bir puanını takiben, tüm beceriler ile ilgili ham puan elde edebilmek için iki denemenin puanlarını toplar. Beceri puanlarının toplanmasıyla birlikte alt test puanları elde edilir. Her iki alt testten de alınabilecek en fazla puan 48'dir.

BüKBÖT 'ün uygulanmasında çocuklar 3’erli gruplar şeklinde uygulamaya alınmıştır. Test uygulanmaya başlamadan önce gruptaki öğrencilere testle ilgili gerekli açıklamalar yapılmış ve çocukların yapacağı beceriyi anlamalarını sağlamak için uygulama ön denemesi araştırıcı tarafından yapılmıştır. Ölçme sürecinde çocukların her beceriyi iki kere yapmaları istenmiştir ve her denemedeki performans kriterleri ayrı ayrı puanlanmıştır. Çocuk tarafından yapılan beceri doğru yapılmış ile 1, yapılmamış ise 0 puan verilmiştir. Uygulama süresi her bir çocuk için ortalama 15 dakika sürmüştür.

Testten elde edilen üç farklı test puanına (lokomotor, nesne kontrol ve büyük kas beceri ham puanı) ait alfa katsayılarının ortancası, lokomotor beceri için; .75, nesne kontrol beceri için; .72, büyük kas beceri için; .78'dir. Bu katsayılar testin güvenli olduğunu ve sonuçların güvenle kullanılabileceğini göstermektedir (Tepeli, 2007).

Burada değerlendirilen ölçeklerin teknik bilgilerinin tablolaştırılması, ölçeklerin kullanım amaçlarını, çalışmaya uygun hedef grubun yaş aralıklarını, ölçeklerle ilgili genel bilgilerin değerlendirilmesi gibi araştırmacılara çalışmalarında kullanmayı düşündükleri ölçeklerle ilgili genel bilgi vermek amacıyla yapılmıştır. 
Özlem KANBiR • Özlem AKKOÇ• Sena KIRLANGIÇ • Ayşe Oya ERKUT

Tablo 1. Motor Gelişim Değerlendirme Ölçekleri

\begin{tabular}{|c|c|c|c|c|c|c|c|}
\hline & TGMD-2 & CHAMPS & BOT-2 & $\begin{array}{l}\text { Peabody Developmental } \\
\text { Motor Scales-2 }\end{array}$ & Movement ABC-2 & $\begin{array}{c}\text { Körperkoordinations } \\
\text { test für Kinder } \\
\text { (KTK) }\end{array}$ & $\begin{array}{c}\text { Büyük Kas Becerilerini } \\
\text { Ölçme Testi } \\
\text { (BüKBÖT) }\end{array}$ \\
\hline Yazarlar & Ulrich, D.A., 2000 & $\begin{array}{l}\text { Williams, H.G., } \\
2009\end{array}$ & $\begin{array}{l}\text { Bruininks R.H. and } \\
\text { Bruininks B.D., } 2005\end{array}$ & Folio and Fewell, 2000 & $\begin{array}{c}\text { Henderson, Sugden } \\
\text { ve Barnett, } 2007\end{array}$ & $\begin{array}{l}\text { Kiphard ve Schilling, } \\
2007\end{array}$ & Tepeli, K. (2007) \\
\hline Amaç & $\begin{array}{l}\text { Motor Davranış } \\
\text { Değerlendirme }\end{array}$ & $\begin{array}{l}\text { Motor Becerileri } \\
\text { Ölçme }\end{array}$ & $\begin{array}{l}\text { Hafif ila orta dereceli } \\
\text { motor koordinasyon } \\
\text { problemleri olan } \\
\text { bireylerde eksikliklerin } \\
\text { belirlenmesi }\end{array}$ & $\begin{array}{l}\text { Kaba ve ince motor } \\
\text { becerileri karşlaştırma } \\
\text { Akranlara göre motor } \\
\text { yeterliliği tahmin etme }\end{array}$ & $\begin{array}{l}\text { Günlük yaşamdaki } \\
\text { motor bozuklukları } \\
\text { tanımlama }\end{array}$ & $\begin{array}{l}\text { Genel dinamik } \\
\text { denge becerisini } \\
\text { değerlendirme }\end{array}$ & $\begin{array}{c}\text { Büyük kas becerilerini, } \\
\text { motor becerilerini } \\
\text { ölçme }\end{array}$ \\
\hline Test Tipi & Norm Referanslı & Norm Referanslı & Norm Referanslı & $\begin{array}{c}\text { Norm } \\
\text { Referansli }\end{array}$ & Norm Referanslı & Norm Referanslı & Norm Referanslı \\
\hline Yaş Aralığ & 3-11 Yaş arası & 3-5 Yaş arası & 4-21 yaş arası & Doğumdan 6 yaşa kadar & 3-16 Yaş arası & 5-14 Yaş arası & 3-10 Yaș arası \\
\hline Test Yapısı & $\begin{array}{c}\text { Kaba Motor ve İnce } \\
\text { motor, alt testler: } \\
\text { Lokomotor } \\
\text { (Koşma, gallop, } \\
\text { sekme, tek ayak, } \\
\text { sıçrama, sıçrayarak } \\
\text { atlama, yatay } \\
\text { atlama, yana } \\
\text { kayma) Nesne } \\
\text { Kontrol (duran } \\
\text { topa vurma, top } \\
\text { sektirme, yakalama, } \\
\text { topa ayakla vurma, } \\
\text { el üstünden top } \\
\text { firlatma) } \\
\end{array}$ & $\begin{array}{c}\text { Test iki alt boyutta } \\
\text { oluşur. } \\
\text { Lokomotor } \\
\text { (Koşma, Durarak } \\
\text { uzun atlama, } \\
\text { Kayma adımı, } \\
\text { Gallop, Siçrama, } \\
\text { Sekme) Nesne } \\
\text { Kontrol (Baş üstü } \\
\text { atış, Aşağıdan } \\
\text { yuvarlama, Ayakla } \\
\text { Vurma, Yakalama, } \\
\text { Sabit Duran Topa } \\
\text { Sopa ile vurma, } \\
\text { Top sektirme) } \\
\end{array}$ & $\begin{array}{l}\text { BOT-2'nin tamamı } 53 \\
\text { maddeye sahiptir ve } \\
8 \text { alt teste ayrılmıştır: } \\
\text { ince motor hassasiyeti } \\
\text { (7 madde), ince } \\
\text { motor entegrasyonu } \\
\text { ( } 8 \text { madde), el } \\
\text { becerisi ( } 5 \text { madde), } \\
\text { ikili koordinasyon } \\
\text { (7 madde), denge } \\
\text { (9 madde), koşma } \\
\text { hızı ve çeviklik (5 } \\
\text { madde), üst ekstremite } \\
\text { koordinasyonu (7 } \\
\text { madde), güç ( } 5 \text { madde). }\end{array}$ & $\begin{array}{l}\text { İnce motor ve kaba } \\
\text { motor skalasi; } 6 \text { alt } \\
\text { testten oluşur } \\
\text { Refleksler } \\
\text { Denge } \\
\text { Lokomotor } \\
\text { Nesne Kontrol } \\
\text { Kavrama } \\
\text { Görsel-Motor } \\
\text { Entegrasyonu }\end{array}$ & $\begin{array}{c}8 \text { test öğesi } \\
3 \text { el becerisi, } \\
2 \text { nişan alma ve } \\
\text { yakalama } \\
3 \text { denge }\end{array}$ & $\begin{array}{l}4 \text { alt öğe } \\
\text { (geriye dengeleme, } \\
\text { tek ayak sekme, } \\
\text { yanlara sıçrama ve } \\
\text { yanlara adımlama) }\end{array}$ & $\begin{array}{l}\text { Kaba Motor ve İnce } \\
\text { motor, alt testler: } \\
\text { Lokomotor (Koşma, } \\
\text { gallop, sekme, tek ayak, } \\
\text { sıçrama, sıçrayarak } \\
\text { atlama, yatay atlama, } \\
\text { yana kayma) Nesne } \\
\text { Kontrol (duran topa } \\
\text { vurma, top sektirme, } \\
\text { yakalama, topa ayakla } \\
\text { vurma, el üstünden top } \\
\text { firlatma) }\end{array}$ \\
\hline \multirow[t]{2}{*}{$\begin{array}{l}\text { Normative } \\
\text { Örnek }\end{array}$} & $\mathrm{N}=1208$ & $\mathrm{~N}=297$ & $\mathrm{n}=1520$ & $\mathrm{n}=2,003$ & $\mathrm{~N}=1172$ & $\mathrm{~N}=1128$ & $\mathrm{~N}=1600$ \\
\hline & TGMD-2 & CHAMPS & BOT-2 & $\begin{array}{l}\text { Peabody Developmental } \\
\text { Motor Scales- } 2\end{array}$ & Movement ABC-2 & $\begin{array}{c}\text { Körperkoordinations } \\
\text { test für Kinder } \\
\text { (KTK) }\end{array}$ & $\begin{array}{c}\text { Büyük Kas Becerilerini } \\
\text { Ölçme Testi } \\
\text { (BüKBÖT) }\end{array}$ \\
\hline
\end{tabular}


Eurasian Research in Sport Science • Avrasya Spor Bilimleri Araştırmaları • ERIS • Cilt 6, Sayı 2 • Aralık 202I, ss. I80-205

\begin{tabular}{|c|c|c|c|c|c|c|c|}
\hline Yöntem & $\begin{array}{l}\text { Testte kullanılacak } \\
\text { materyaller testin } \\
\text { şartlarına uygun } \\
\text { olarak hazırlanır ve } \\
\text { iki defa uygulanır. }\end{array}$ & $\begin{array}{l}\text { Ölçüm yapılırken } \\
\text { önce araştırmacı } \\
\text { hareketi gösterir } \\
\text { ve uygulama için } \\
\text { çocuğa iki deneme } \\
\text { hakkı verilir. iki } \\
\text { denemde ölçüm } \\
\text { formuna işlenir. }\end{array}$ & $\begin{array}{l}\text { Araştırmacı tarafından } \\
\text { Sözlü uyaranlar ve } \\
\text { gösteri tekniği ile tüm } \\
\text { hareketlerin tek tek } \\
\text { anlatımı yapılmış ve } \\
\text { hareketleri daha iyi } \\
\text { anlamaları için her } \\
\text { maddede deneme } \\
\text { yapmalarına izin } \\
\text { verilmiştir. Her bir } \\
\text { maddenin hemen } \\
\text { arkasından her } \\
\text { birey için ayrı ayrı } \\
\text { düzenlenmiş formlara } \\
\text { uygulama puanları } \\
\text { kaydedilmektedir. }\end{array}$ & $\begin{array}{c}\text { Araştırıcı } \\
\text { standartlaştırılmış } \\
\text { talimatlar ve } \\
\text { materyalleri kullanarak } \\
\text { ortaya çıan öğeleri } \\
\text { yönetir }\end{array}$ & \begin{tabular}{|c} 
Tüm öğeleri \\
değerlendirmek için \\
iki deneme hakkı \\
verilir ve en iyi \\
deneme puanı esas \\
alınır.
\end{tabular} & $\begin{array}{l}\text { Her bir çocuk, } \\
\text { geriye dengeleme, } \\
\text { tek ayak sekme, } \\
\text { yanlara sıçrama ve } \\
\text { yanlara adımlama } \\
\text { (platformla) olan } \\
\text { dört fiziksel testi } \\
\text { uygular. }\end{array}$ & $\begin{array}{l}\text { Araştırıcı öncelikle } \\
\text { çocuklara gösterir daha } \\
\text { sonra her çocuk iki } \\
\text { deneme hakkı verilir. } \\
\text { Her iki denemenin } \\
\text { puanı da kaydedilir. }\end{array}$ \\
\hline Süre Aralığ 1 & 15-20 dakika & 25-30 dakika & 45-60 dakika & 45-60 dakika & 20-40 Dakika & 15-20 dakika & 15-20 dakika \\
\hline Puanlama & $\begin{array}{l}2 \text { puanlık ölçek } \\
(0-1)\end{array}$ & $\begin{array}{c}2 \text { puanlık ölçek } \\
(0-1)\end{array}$ & $\begin{array}{c}2 \text { puanlık ölçek ile } 13 \\
\text { puanlık ölçek arasında } \\
\text { değişmektedir. Ham } \\
\text { puanlar standart } \\
\text { puanlara dönüştürülür. }\end{array}$ & 3 puanlık ölçek $(0,1,2)$ & $\begin{array}{c}6 \text { puanlık } \\
\text { derecelendirme } \\
\text { puanı vardır }(0-5)\end{array}$ & $\begin{array}{c}6 \text { puanlik } \\
\text { derecelendirme }\end{array}$ & 2 puanlık ölçek (0-1) \\
\hline $\begin{array}{l}\text { Toplam Puan } \\
\text { Türleri }\end{array}$ & $\begin{array}{c}\text { Yüzdelik sıra, } \\
\text { Standart puanlar, } \\
\text { yaş eșdeğeri, Kaba } \\
\text { Motor Bölümü }\end{array}$ & $\begin{array}{l}\text { Yüzdelik sıra, } \\
\text { Standart puanlar, } \\
\text { yaş eşdeğeri, } \\
\text { lokomotor ve } \\
\text { nesne kontrol }\end{array}$ & $\begin{array}{c}\text { Alt test ve bileşik } \\
\text { puanlar, Toplam Motor } \\
\text { Bileşimi; Standart Puan, } \\
\text { Ölçek puanı, Yüzdelik } \\
\text { dilimler, Standart } \\
\text { sapmalar }\end{array}$ & $\begin{array}{l}\text { Yaş eşdeğeri, yüzdelik } \\
\text { dilim, standart puan (alt } \\
\text { testler), bileşik bölüm } \\
\text { (ince ve kaba motor) }\end{array}$ & $\begin{array}{l}\text { Yüzdelik dilim, } \\
\text { Standart puanlar, } \\
\text { Z-puanı, T-puanı, } \\
\text { AE, ölçekli puan, } \\
\text { ortalama }\end{array}$ & $\begin{array}{l}\text { Yüzdelik sıra, Motor } \\
\text { bölüm }\end{array}$ & $\begin{array}{l}\text { Yüzdelik sıra, yaş } \\
\text { eşdeğerleri, cinsiyet } \\
\text { farklılıkları, nesne } \\
\text { kontrol, lokomotor } \\
\text { kontrol puanları }\end{array}$ \\
\hline $\begin{array}{l}\text { Puanlayıcılar } \\
\begin{array}{lllll}\text { A } & \mathrm{r} & \mathrm{a} & \mathrm{s} & 1 \\
\text { Güvenirlilik }\end{array}\end{array}$ & .98 & $\begin{array}{l}\text { Lokomotor alt } \\
\text { ölçeğinde } .99, \\
\text { nesne kontrol } \\
\text { alt ölçeğinde } .98 \\
\text { ve toplamda } .94 \\
\text { puandır. }\end{array}$ & .98 & $\begin{array}{c}.96 \\
\text { (Toplam Test) }\end{array}$ & \begin{tabular}{|c} 
Rapor edilen \\
güvenirlilik \\
TOMI-H n: 3603 \\
değerlendirici ICC= \\
$.70 \% 62-100$
\end{tabular} & $>.85$ & .99 \\
\hline
\end{tabular}


Tablo 2. Motor Gelişim Değerlendirme Ölçekleri Geçerlik ve Güvenirlik Değerleri

\begin{tabular}{|c|c|c|c|c|c|c|c|}
\hline & TGMD-2 & CHAMPS & BOT-2 & \begin{tabular}{|c|} 
Peabody \\
Developmental \\
Motor Scales-2 \\
\end{tabular} & $\begin{array}{l}\text { Movement } \\
\text { ABC-2 }\end{array}$ & $\begin{array}{l}\text { Körperkoordinations } \\
\text { test für Kinder (KTK) }\end{array}$ & $\begin{array}{c}\text { Büyük Kas Becerilerini } \\
\text { Ölçme Testi } \\
\text { (BüKBÖT) }\end{array}$ \\
\hline $\begin{array}{l}\text { Test } \\
\text { Tekrar test } \\
\text { Güvenirliği }\end{array}$ & $\begin{array}{c}\text { Lokomotor }=.85 \\
\text { Nesne Kontrol: } \mathrm{r}= \\
.88 \text { Büyük Motor } \\
\text { Quent: } \mathrm{r}=.91\end{array}$ & $\begin{array}{c}\text { Lokomotor: } .98 \\
\text { Nesne Kontrol: } \\
.97 \\
\text { Toplam puan: } .90\end{array}$ & $\begin{array}{c}\mathrm{n}=134, \text { Ortalama alt test } \\
\text { korelasyon katsayıları } .69 \text { ile } \\
.70 \text { s arasında değişmektedir. } \\
\text { Ortalama bileşik korelasyon } \\
\text { katsayıları } .77 \text { ile düşük } .80 \mathrm{~s} \\
\text { arasında değişmektedir. } \\
\text { Alt test güvenilirliği yüksek } \\
.70 \text { ile düşük } .80 \text { arasında } \\
\text { değişmektedir. }\end{array}$ & $\begin{array}{c}\mathrm{r}=.89 \text { (toplam } \\
\text { test, } 2-11 \text { ay } \\
\text { yaş); } \\
\mathrm{r}=.96 \text { (toplam } \\
\text { test, } 12-17 \text { ay } \\
\text { yaş) }\end{array}$ & \begin{tabular}{|c|} 
TOMI-H \\
$\mathrm{n}=360,3$ \\
değerlendirici \\
için rapor edilen \\
güvenilirlik: \\
ICC $=.75 ; .64$ \\
$(4-6)$, \\
$.43(6-8),$. \\
$96(9-10),$. \\
$97(11-12)$
\end{tabular} & $\begin{array}{c}\mathrm{r}>.85 \text { Test ve tekrar } \\
\text { test arasındaki } \\
\text { ortalamaların } \\
\text { karşllaştırılması } \\
\text { (tümü önemli değil) }\end{array}$ & $\begin{array}{c}\text { Lokomotor }=0.99 \\
\text { Nesne Kontrol: } \mathrm{r}=.99 \\
\text { Büyük Kas Beceri: } \mathrm{r} \\
=.99\end{array}$ \\
\hline $\begin{array}{l}\text { Yapı } \\
\text { Geçerliliği }\end{array}$ & $\begin{array}{c}\text { - kronolojik ile } \\
\text { korelasyon } \\
\text { yaş } \\
\text { - grupları arasında } \\
\text { farklılaşma } \\
\text { ortalamanın altında } \\
\text { bireyler } \\
\text { ve yukarıda } \\
\text { - Maddeler, alt } \\
\text { testlerin Toplam } \\
\text { puanıyla yüksek } \\
\text { oranda korelasyon } \\
\text { gösterir } \\
\text { - alt test bileşikleri } \\
\text { birbirleriyle } \\
\text { ilişkilidir } \\
\text { - faktör analizi: } \\
90 \text { ile } .96 \text { arasında } \\
\text { değişen uyum iyiliği } \\
\text { indeksleri }\end{array}$ & $\begin{array}{l}\text { Faktör analiz, } \\
\text { Lokomotor ve } \\
\text { Nesne kontrol } \\
\text { arası, Yaş grupları } \\
\text { arası korelasyon }\end{array}$ & $\begin{array}{c}=.78(.56-.86) \text { (test } \\
\text { puanları / kronolojik yaş) } \\
\text { Çocukların tipik olarak } \\
\text { gelişip gelişmediğine veya } \\
\text { farklı derecelerde gelişimsel } \\
\text { zorluk yaşayıp yaşamadığına } \\
\text { göre değişen puanlarla ayırt } \\
\text { edici geçerlilik }\end{array}$ & \begin{tabular}{|l} 
Faktör Analizi \\
Yaş ile ilişkili \\
alt test puanları
\end{tabular} & N/A & $\begin{array}{c}\text { Yapının geçerliliği } \\
\text { kanıtlanmış aşağıdaki } \\
\text { varsayımların } \\
\text { incelenmesi: } \\
\text {-sosyo-kültürel } \\
\text { yokluğun farkı } \\
\text { (kentsel ve kırsal } \\
\text { çocuklar) } \\
\text {-maddede cinsiyet } \\
\text { farklılaşması dahil } \\
\text { edilen normatif } \\
\text { veriler } \\
\text {-dezavantaj için } \\
\text { farklılaşmış çocuklar } \\
\text { (beyin bozukluğu, } \\
\text { davranış sorunları, } \\
\text { sessizlik) geliştirme } \\
\text { yaşla ilişkilidir. }\end{array}$ & $\begin{array}{l}\text { Performanslar yaşla } \\
\text { ilgili olmalıdır, alt } \\
\text { testlerin maddeleri } \\
\text { onların alt testlerinin } \\
\text { toplam puanıyla } \\
\text { ilişkilidir, Büyük } \\
\text { kas becerisini } \\
\text { ölçtüğünden kendileri } \\
\text { arasında ilişkili } \\
\text { olmalıdır, Gruplar } \\
\text { ortalama değerler } \\
\text { farklılaşmalıdır, Alt } \\
\text { becerilerin faktör } \\
\text { analizleri modelde } \\
\text { kalıtsal olarak bulunan } \\
\text { yapılar ve becerileri } \\
\text { ilişskiyi doğrular. }\end{array}$ \\
\hline
\end{tabular}


Eurasian Research in Sport Science • Avrasya Spor Bilimleri Araştırmaları • ERIS • Cilt 6, Sayı 2 • Aralık 202I, ss. I80-205

\begin{tabular}{|c|c|c|c|c|c|c|c|}
\hline $\begin{array}{l}\text { Kapsam } \\
\text { İçerik } \\
\text { Geçerliliği }\end{array}$ & $\begin{array}{l}\text { Üç içerik uzmanı, } \\
\text { seçilen becerilerin } \\
\text { okul öncesi ve } \\
\text { ilkokulda öğretilip } \\
\text { öğretilmediğine } \\
\text { karar vermiştir. }\end{array}$ & \begin{tabular}{|c|} 
CMSP'yi gerçek \\
test ortamında \\
yönetmeden önce, \\
motor gelişimde \\
geçmişi olan \\
profesyoneller \\
olan iki test \\
uzmanının \\
kapsamlı eğitimi \\
tamamlamıştır. \\
\end{tabular} & $\begin{array}{l}\text { Teorik ve deneysel kanıt } \\
\text { kaynakları test içeriğini, } \\
\text { madde uyumunu ve klinik } \\
\text { grupları içerir. }\end{array}$ & $\begin{array}{c}\text { Madde Tepki } \\
\text { Teorisi } \\
\text { Madde } \\
\text { ayrımcıllk } \\
\text { katsayıları } \\
\text { bildirildi } \\
\text { İç tutarlılık .97 } \\
\text { (toplam puan) }\end{array}$ & $\begin{array}{c}\text { Uzmanlar } \\
\text { tarafindan } \\
\text { incelenen } \\
\text { maddeler ve } \\
\text { alt testler arası } \\
\text { korelasyon } \\
\text { kabul edilebilir. }\end{array}$ & $\begin{array}{l}\text { Faktör analizleri, } \\
\text { testin dinamik vücut } \\
\text { koordinasyonunu } \\
\text { ve vücut kontrolünü } \\
\text { (dinamik denge) } \\
\text { değerlendirdiğini } \\
\text { göstermiştir. }\end{array}$ & $\begin{array}{c}\text { Dört bağımsız } \\
\text { hakem tarafından } \\
\text { değerlendirilmiş, } \\
\text { hakemler arası intra- } \\
\text { class korelasyonu .87 } \\
\text { olarak hesaplanmıştır. }\end{array}$ \\
\hline $\begin{array}{l}\text { Ölçüt } \\
\text { geçerliliği }\end{array}$ & $\begin{array}{l}\text { Kısmi korelasyonlar } \\
\text { TGDM ve CSSA } \\
\text { (Comprehensive } \\
\text { scales of student) alt } \\
\text { testleri: Lokomotor } \\
.63 \text { ve Nesne } \\
\text { kontrolü için .41. }\end{array}$ & $\begin{array}{c}\text { CMSP ve } \\
\text { TGDM-2 } \\
\text { ölçeklerinin } \\
\text { lokomotor alt } \\
\text { ölçeklerinin .98; } \\
\text { Nesne Kontrol } \\
\text { alt ölçeklerinin } \\
.97 \text { ve toplam } \\
\text { puanlarının .98 } \\
\text { aldıkları tespit } \\
\text { edilmiştir. }\end{array}$ & $\begin{array}{c}\text { BOTMP - BOT-2 Alt test } \\
\text { ve bileşik puanlar için orta } \\
\text { ile güçlü korelasyonlar } \\
\text { (.45 - .73); TMC ve BC } \\
\text { için yüksek korelasyon .80. } \\
\text { PDMS-2 - BOT - 2: TMC } \\
\text { ve TMQ güçlü bir şekilde } \\
\text { ilişkilidir (.73); alt test ve } \\
\text { bileşik korelasyonlar orta } \\
\text { ile yüksek düzeydedir (.35 } \\
\text { - .75). TVMS-R - BOT-2: } \\
\text { İnce Motor Entegrasyonu alt } \\
\text { testinin korelasyonu .74. }\end{array}$ & $\begin{array}{c}\text { PDMS r }=.84 \\
\text { (Kaba Motor) } \\
\mathrm{r}=.91 \text { (İnce } \\
\quad \text { Motor) } \\
\text { Mullen } \mathrm{r}=.86 \\
\text { (Kaba Motor) } \\
\mathrm{r}=.80 \text { (İnce } \\
\quad \text { Motor) }\end{array}$ & $\begin{array}{c}\text { BOTMP ile } \\
\text { eşzamanlı } \\
\text { geçerlilik r = } \\
-.53 \text { ve KTK r = } \\
.62 \text { ile }\end{array}$ & $\mathrm{N} / \mathrm{A}$ & $\mathrm{N} / \mathrm{A}$ \\
\hline
\end{tabular}




\section{YÖNTEM}

Bu çalışmada belli dönemlerde yayınlanmış olan çocuklarda motor gelişimin seviyelerini belirleme için kullanılan ölçeklerin dikkate alınarak ulusal ve uluslararası literatürlerin incelenmesi ile geleneksel derleme modeline göre düzenlenmiştir. Geleneksel derleme modeli, belirlenmiş olan bir konuda yayınlanmış olan birden fazla araştırmanın incelenmesi ve bu inceleme sonucunda araştırmanın bulgularını, sonuçlarını ve değerlendirmelerini yorumlayan çalışmalardır. Geleneksel derlemede çoğunlukla o alanda çalışan ve uzmanlaşan kişiler tarafından belirli bir yöntem izlenmeksizin, farklı kaynaklar ve şekillerde elde edilen verilerin derlenmiş olduğu alan yazılarıdır (Burns ve Grove, 2009; Gerrish ve Lacey, 2010; Moule ve Goodman, 2009 akt; Karaçam, 2013).

\section{Motor Değerlendirme Testlerinin Güçlï ve Zayıf Yönleri}

\section{Güçlï Yönler:}

Movement ABC: Okul öncesi çocukların yaşları için uygundur. Güçlü olmasının bir sebebi testin uluslararası normatif verilerinin mevcut olmasıdır. Ayrıca hem nitel hem nicel değerlendirme imkânı vardır. ABC, çocukların motor bozukluk düzeyini ve gelişimdeki gecikmeyi belirlemek için çok uygundur. Eğitim ortamında kullanılabilmesi güçlü yönleri arasında yer almaktadır. Ayrıca testin psikometrik nitelikleri üzerine çok sayıda çalışma mevcuttur. Diğer bir güçlü olan yönü ise, kısa süre içerisinde geniş örnek taramalarına olanak sağlayan uygulama açısından basit bir test olmasıdır.

CHAMPS: Okul öncesi dönem çocuklarına uygun olması ve hareket becerilerini ayrıntılı maddelerle ölçmesi testin güçlü yönlerindendir. Ayrıca ölçüm için zorunlu olarak alınması gereken bir araç, gereç, kiti bulunmamaktadır. Uygulamada kullanılacak araç, gereçler, kolaylıkla ulaşılabilecek farklı boyutlarda ve özelliklerde toplar, çocuklara uygun hafiflikte ve malzemede beyzbol sopası, çocukların sopayla duran topa vuruş yapabilmesi için topun üzerinde duracağı platform gibi malzemelerdir. CHAMPS, lokomotor ve nesne kontrol hareket becerisi geliştirmeye vurgu yapar.

BOT-2: Okul öncesi çocuklar için uygundur. Çok detaylı bir değerlendirme testidir. Ölçeğin alt test bileşenleri ayrı ayrı değerlendirilebilir. Ayrıca genel hareket becerisi gelişimi için kısa form değerlendirmesi mevcuttur. Aynı zamanda beceri seviyesinin hem altında kalmış çocuklar için hem de üstünde olan çocuklar için beceri uzmanlığı hakkında bilgi sağlar. Çocuğun hareket davranışının niteliksel yönlerinin dahil edilmesi oldukça önemlidir. Bir diğer güçlü yönü ise, testin psikometrik nitelikleri hakkında büyük miktarda kanıt bulunmasıdır.

Peabody Motor Gelişim Ölçeği-2: Okul öncesi çocuklar için uygundur. Çocuklar için çok detaylı bir değerlendirme aracıdır. Ölçeğin alt testleri ayrı ayrı değerlendirilebilir. Ölçek beceri seviyesinin hem altında kalmış çocuklar için hem de üstünde olan çocuklar için beceri uzmanlığı hakkında bilgi sağlar. Hareket davranışının niteliksel yönlerinin dahil edilmesi güçlü yönleri arasında yer almaktadır. Ayrıca çocukların kaba ve ince motor gelişim düzeylerini ayrıntılı maddelerle ölçmek için geliştirilmesi diğer güçlü yönlerinden biridir. 
TGMD-2: Okul öncesi çocuklar için uygundur. TGMD, hareket davranışının niteliksel yönlerinin dahil edilmesi açısından önemli bir testtir. Ayrıca nesne kontrol hareket becerisi geliştirmeye vurgu yapar. Aynı zamanda beceri seviyesinin hem altında kalmış çocuklar için hem de üstünde olan çocuklar için beceri uzmanlığı hakkında bilgi sağlar.

KTK: Bu ölçek, denge becerisinin hızlı taranması yönüyle çok güçlü ve önemlidir. Doğruluğu ve standardizasyonundan dolayı hala çok güvenilir ve çok değerli olarak kabul edilmektedir.

BüKBÖT: Çocuğun bir beceriyi yapıp yapmamasından çok, çocukların beceri esnasında gövde, kol ve bacaklar arasındaki koordinasyonunun nasıl olduğunu ölçmektedir. $\mathrm{Bu}$ da çocuğun becerisine yönelik eğitim programı hazırlanabilmesi açısından testin sunduğu güçlü yönlerden birisidir. BüKBÖT, lokomotor ve nesne kontrol hareket becerisi geliştirmeye vurgu yapar. Ayrıca çocukların büyük kas becerilerini ölçme konusunda önemli olup, gelişimsel gereklilikleri erken tespit edebilmesi testi güçlü kılmaktadır.

\section{Zayıf Yönler:}

Movement $A B C$ : Teste ait beceri seviyesinin üzerinde beceri uzmanlığı bilgisi yoktur. Test edilen öğelerin değerlendirme süresine karşı elverişsiz oranı olması testin oldukça düşük verimliliğine sebep olmaktadır. Ayrıca küçük çocuklar için özel olarak tasarlanmaması testin zayıf yönleri arasında yer almaktadir.

CHAMPS: Ölçüm iki alt boyuttan ve toplam 70 maddeden oluşmaktadır. Bir çocuğun ölçümünün tamamlanması ortalama 25-30 dakika sürmektedir. Ayrıca çocuğun ince motor hareket becerisi gelişimini değerlendirmemesi testin zayıf yönlerindendir.

BOT-2: Testin önem verdiği nokta dezavantajlıların tespiti üzerinedir. Test Avrupa normatif verilerinden yoksundur. Ölçüm kiti almak oldukça karmaşık ve anlaşılması zordur. Ayrıca testin standardizasyonu oldukça zordur. Aynı zamanda küçük çocuklar için tam testin yapılması çok uzun sürmektedir. Koşu maddesinin uygulanabilirliği için geniş bir alana ihtiyaç vardır. Aynı zamanda kafa karıştırıcı puan cetveline sahip olması da testin zayıf yönleri arasında yer almaktadır.

Peabody Motor Gelişim Ölçeği-2: Çocukta olan eksiklikleri / motor bozuklukları tespit etmek için özel olarak tasarlanmıştır. Kısa formu bulunmamaktadır. Dolayısıyla küçük çocuklar için tam testin yapılması oldukça uzun sürmektedir. Ayrıca Avrupalı çocuklara ilişkin normatif verilerin olmaması zayıf yönleri arasında yer almaktadır.

TGMD-2: İnce hareket becerisi ve denge hareket becerisi gelişimini değerlendirmez. Ayrıca Avrupa'da kültürler arası farklılıkta çok belirleyici bir batarya olarak kullanılmamaktadır.

KTK: Test hakkında eski normatif veriler bulunmaktadır. Okul öncesi düşük yaş grubu çocuklarında sadece tek taraflı bir değerlendirme (denge) olması, testin zayıf yönlerindendir. 
BüKBÖT: Çocuğun ince hareket becerisi gelişimini değerlendirmemesi testin zayıf yönüdür. $\mathrm{Bu}$ alanda yapılmış ölçeklerden biri olan BüKBÖT sadece Türk çocuklar ile çalışılmış olup, farklı kökenli çocuklar üzerinde bir çalışması yapılmamıştır. Dolayısıyla yeterli uluslararası normatif verilerin mevcut olmaması ölçeğin zayıf yönlerindendir.

\section{Testlerin Geçerlik ve Güvenirlik Değerlendirmesi}

TGMD-2, iç tutarlık ve kararlık katsayılarını rapor eder (Ulrich, 2000). Bununla birlikte, TGMD-2 test-tekrar test güvenirliği, eski TGMD’nin ilk sürümüne kıyasla hiçbir gelişme göstermemektedir. Tamamlanmış 30 protokolü iki kez analiz eden prosedür, bir test-tekrar test durumuyla eşleşmez ve zaman içindeki bir kararlılık ölçümü olarak değerlendirilemez (Simons ve Van Hombeeck, 2003).

TGMD-2, Tepeli (2007) tarafından Büyük Kas Becerilerini Ölçme Testi (BüKBÖT) olarak Türkçeye uyarlanmış olup geçerlik ve güvenirlik çalışması yapmıştır. Lokomotor beceri için; .75, nesne kontrol beceri için; .72, büyük kas beceri için; .78'dir. Bu katsayılar testin güvenli olduğunu ve sonuçların güvenle kullanılabileceğini göstermektedir.

CHAMPS Motor Beceriler Protokolü, TGMD-2 ile aynı temel motor becerileri ölçmektedir fakat bu testlerin farklılaştığ 1 kısımlar yaş grubu ve madde sayıları ile ilişkilidir. CHAMPS Motor Beceriler Protokolü daha fazla madde sayısı ve daha ayrıntılı hareket analizi sağlaması noktasında TGMD-2 ile farklılık göstermektedir (Kılıç, 2017). CHAMPS Motor beceriler Protokol'ünün geçerlik çalışmasında TGMD-2 testi ile yapılmıştır. Testlerin karşılaştırılmasında Pearson Korelasyon Analizi kullanılmış olup, analiz sonuçlarına göre CMSP ile TGMD-2 ölçeklerinin lokomotor alt ölçeği .98; nesne kontrol alt ölçeği .97; ve toplam puanların .98 aldıkları bulunmuştur. CHAMPS Motor beceriler protokolünün güvenirlik çalışmasında lokomotor alt ölçeğinde .99 , nesne kontrolü alt ölçeğinde .98 ve toplamda .94 olarak bulunmuştur (Williams ve diğ.,, 2009).

CHAMPS Motor Becerile Protokolü (CMSP) 4 ve 5 yaş çocuklarına Türkçeye uyarlama çalışması Kılıç (2017) tarafından yapılmıştır. Kılıç’ın yapmış olduğu uyarlama çalışmasında kriter geçerliği için CHAMPS Motor Beceriler Protokolü ile orijinal adı Test of Gross Motor Development-2 (TGMD2) olan, Tepeli (2007) tarafından Büyük Kas Becerilerini Ölçme Testi (BüKBÖT) olarak Türkçeye uyarlanan ölçme aracı ile yapılmıştır (Kılıç, 2017). Geçerlik analizleri sonucunda yer değiştirme hareketleri alt ölçeği .89; nesne kontrol alt ölçeği .90 ve motor beceriler toplam puan1 .92 olarak bulunmuştur. CHAMPS Motor Beceriler Protokolü güvenirlik çalışmasında Pearson korelasyon sonuçlarl; yer değiştirme .925 , nesne kontrolü .942 ve motor beceriler toplamı .941 olarak tespit edilmiştir.

Peabody Motor Gelişim Ölçeği-2 Folio ve Fewell (2000) tarafından yapılan güvenirlik çalışmasında, alt boyutların iç tutarlık katsayı puanlarının .89 ile .96 arasında değiştiği sonucuna ulaşılmıştır. Ölçeğin toplamına ilişkin iç tutarlık katsayısı .97 , kaba ve ince motor bölümlerinin her birinin katsayısı ise .96'dır. Ayrıca 36-47 aylık çocuklara yönelik hesaplanan katsayı değerleri alt boyutlar için .71 ile 95 arasında iken; kaba motor boyutu için .93, ince motor boyutu için ve ölçeğin tümü için .95’tir. 
Peabody Motor Gelişim Ölçeği Türkçeye uyarlama çalışması Taştepe (2018) tarafından 36-47 aylık çocuklar ile yapılmıştır. Yapılan güvenirlik analizlerinde gruplar ikiye ayrılmıştır. 36-41 aylık çocukların ( $\mathrm{n}=59)$ olduğu grup alt boyut iç tutarlık puanı kaba motor için .90, ince motor için ise .81dir. 42-47 aylık çocukların $(\mathrm{n}=132)$ alt boyut iç tutarlık puanı kaba motor için .86, ince motor için ise .84 'tür. Test - tekrar test puanı kaba motor için .99 , ince motor için .98'dir.

Bruininks - Oseretsky Motor Yeterlik Testi, Bruininks (2005) tarafından güncellenerek BruininksOseretsky Test-2 (BOT2) halini almıştır. BOT-2 değerlendiriciler arası güvenirlik kısa form alt testleri için .90'dır. BOT-2 test-tekrar test güvenirliği için üç farklı yaş grubunda .80'dir. BruininksOseretsky Motor Yeterlik Testi uzun versiyon Türkçeye uyarlama çalışması Mülazımoğlu ve Gürsoy (2012) tarafından 5-6 yaş grubu Türk çocukları için yapılmıştır. BOT-2 kısa versiyon Türkçe uyarlama çalışması Köse (2018) tarafından yapılmış olup, çalışmanın yapı geçerliği Mann-Whitney U testi kullanılarak incelenmiş, istatiksel anlamlılık düzeyi 0,05 olarak kabul edilmiştir. Bunun sonucunda BOT-2 ince motor doğruluk ve dayanıklılık alt testleri hariç diğer bütün testlerde istatiksel açıdan kontrol grubunun performansı çalışma grubunun performansından daha iyi düzeyde bulunmuştur ( p <0,05). BOT-2 kısa formunun test - tekrar test yönteminin istatiksel analizi ICC (sınıf içi korelasyon katsayısı) karma model olarak kullanılarak yapılmıştır. ICC değerlerinin yorumlanmasında kullanılan aralıklar; .5’ten küçük ise zayıf güvenirlik, .50 ile .74 arasındaki değerler orta derecede güvenirlik, .75 ile .90 arasındaki değerler iyi derecede güvenirlik ve .90 'dan büyük değerler ise mükemmel derecede güvenirlik şeklinde tanımlanmıştır (Portney, 2000). BOT-2 ince motor doğruluk alt testi .57 ve el becerisi alt testi .74 orta derecede güvenilir olarak bulunmuştur. Bu iki test dışında kalan diğer testler iyi derecede güvenilir olarak bulunmuştur (Köse, 2018).

Kiphard ve Schilling (1974) tarafından geliştirilen ve 2007 yılında tekrar modernizasyonu yapılan 5-14 yaş çocuklar için motor koordinasyonu ölçen Körperkoordinations Test für Kinder (Çocuk Beden Koordinasyonu) yapılan geçerlik ve güvenirlik analizlerinde güvenirlik değeri $\mathrm{r}=.85$ ve geçerlik değeri $r=.60-.80$ olarak bulunmuştur. Bu sonuçlara göre çocukların motor becerilerini değerlendirmeye yönelik güvenilir bir ölçme aracıdır (Kiphard ve Schilling, 2007; Livonen, Saakslahti ve Laukkanen, 2016). Çocuk Beden Koordinasyonu Testinin Ortaokul Türk Çocukları İçin Geçerlik ve Güvenirlik Çalışması Özkara ve Kalkavan (2018) tarafından yapılmıştır. Bu çalışmanın analiz sonuçlarına göre kapsam geçerliği KGİ=.95, yapı geçerliği analizleriyle elde edilen eş zaman geçerliği $r=.95$ 'dir. KTK testinin güvenirliğine ilişkin sonuçlar ise, test-tekrar test r=.90’dır (Özkara ve Kalkavan, 2018).

Çocuk Hareket Değerlendirme Bataryası (MABC-2) Henderson ve Sugden (1992) tarafindan Test of Motor Impairment (TOMI) - Motor Yetersizlik Testinden revize edilerek oluşturulan bir testtir. Henderson ve Sugden tarafından 2007 yılında tekrardan revize edilmiştir. Testin analiz çalışmalarında toplam test puanlarının güvenirlik katsayısı .80'dir (Henderson ve diğ.,, 2007). 


\section{TARTIŞMA ve SONUÇ}

\section{Motor Değerlendirme Araçları ile İlgili Alanda Yapılan Çalışmalar}

TGMD-2 Ulrich (2000) tarafından motor davranışları değerlendirme amacıyla geliştirilmiştir. 4-5 yaş arası Belçikalı ve Amerikalı 326 okul öncesi çocukta gerçek ve algılanan motor yeterlik üzerine yapılan bir çalışmada, test sonucuna göre kültürel farklılıklar bulunmuştur (Brian ve diğ.,, 2018). 275 Afro-Amerikalı ve 194 İspanyol okul öncesi çocuklar ile nesne kontrol ve lokomotor beceri üzerine yapılan bir çalışmada her iki bölgenin de çocuklarında gelişimsel olarak bir gecikme ortaya çıkmıştır (Goodway, Robinson, ve Crowe, 2010). TGMD-2 ve MABC-2'nin karşılaştırıldığı başka bir çalışmada iki testin farklı alanları test ettiği, birbirinin yerine kullanılmaması gerektiği bunun yerine birbirini tamamlar nitelikte olduğu sonucuna ulaşılmıştır (Logan ve diğ.,, 2012). Büyük Kas Motor Gelişim-2 (TGMD-2) testinin Türk çocuklarına uyarlama çalışmasında iç tutarlık, test tekrar test güvenirliği ve faktör analizi sonuçlarına göre Türk çocukları için geçerli ve güvenilir olduğu sonucuna varılmıştır (Boz ve Aytar, 2012). TGMD-2 geçerlik güvenirlik çalışmalarına bakıldığında Brezilyalı çocuklar (Valentini, 2012) ve Portekizli (Lopes, Saraiva, ve Rodrigues, 2018) çocuklar için benzer sonuçlar çıkmış ve geçerlik ve güvenirliğin sağlandı̆̆ 1 sonucuna ulaşılmıştır.

CHAMPS Motor Beceriler Protokolü Williams (2009) tarafından motor becerileri ölçme amacıyla geliştirilmiştir. CHAMPS Motor Beceriler Protokolünün (CMSP) 4-5 yaş çocuklarına yönelik yapılan Türkçeye uyarlama çalışmasında ölçüt geçerliğinin, test tekrar test güvenirliğinin ve iç tutarlık değerlerinin sonuçlarına göre geçerli ve güvenilir bir ölçme aracı olduğu sonucuna varılmıştır (Kılıç, Uyanık ve Sarı, 2017). Okul öncesi çocuklarda motor beceri performansını ve fiziksel aktiviteyi inceleyen bir çalışmada nesne kontrol skorları için kriterler arasında hiçbir fark bulunmamıştır. Daha zayıf motor beceri performansına sahip çocuklar, daha iyi gelişmiş motor becerileri olan çocuklardan daha az aktif durumdadır. Motor beceri performansı ile fiziksel aktivite arasındaki bu ilişki, özellikle obezitenin önlenmesinde çocukların sağlığı için önemli olabildiği sonucuna varılmıştır (Williams ve diğ.,, 2009).

BOT-2 Bruininks ve Bruininks (2005) tarafından hafif ile orta dereceli motor koordinasyon problemleri olan bireylerde eksikliklerin belirlenmesi amacıyla geliştirilmiştir. Hafif düzeyde zihinsel engelli çocuklara uygulanan serbest zaman aktivitelerinin fiziksel uygunluk ve motor gelişimleri üzerine etkisinin incelendiği bir çalışmada 24 haftalık serbest zaman aktivitelerinin hafif zihinsel engelli çocukların motor yeterliklerini ve fiziksel uygunluklarını geliştirdiği bulunmuştur. Son testlerden 24 hafta sonra yapılan kalıcılık test sonuçlarına göre de aktivitelerden sonra kazanılan becerilerin gerilediği görülmüştür (Karakaş, 2018). BOT-2 8 alt ölçek ve 4 bileşik ölçeğin yapısal geçerliğinin incelendiği bir çalışmada 8 alt ölçek ve 4 bileşik ölçeğin tümü, tüm katsayıları >.95 olan mükemmel madde güvenirliğine sahip bulunmuştur. BOT-2 alt ölçeklerinin ve bileşik ölçeklerin bir kısmı boyutsallık, hiyerarşik sıralama, DIF (differential item functioning) ve güvenirlik ile ilgili iki veya daha fazla problem durumu ile ilişkili görünmektedir. FMI (fine motor integration), BC (bilateral coordination), B (balance), RSA (running-speed agility) ve BCC (body coordination 
composite). Bu nedenle BOT-2 alt ölçeklerinin ve bileşik ölçeklerin yalnızca bir kısmı güvenle kullanılabilir sonucuna ulaşılmıştır (Brown, 2019). 5-15 yaş arası okula giden çocuklarda BOT-2 kullanarak bilateral koordinasyonun değerlendirildiği bir çalışmada erkek çocukların kızlardan daha iyi performans gösterdiği ve yaş arttıkça performansın da arttığı sonucuna varılmıştır (Karambe, Dhote, ve Palekar, 2017). 7-12 yaş arası okula giden aşırı kilolu ve obez çocukların BOT-2 kullanarak ince motor kontrolünün değerlendirildiği bir çalışmada 7-12 yaş arası obez öğrencilerin \%59,3’ünün ince motor kontrol bozukluğuna sahip olduğu ortaya çıkmıştır (Preeti ve diğ.,, 2019).

PDMS-2 Folio ve Fewell (2000) tarafından kaba ve ince motor becerileri karşılaştırma ve akranlara göre motor yeterliği tahmin etme amacıyla geliştirilmiştir. 36-47 aylık çocuklarda yapılan Peabody Motor Gelişim Ölçeği-2'nin uyarlama çalışmasında kapsam geçerliği, yapı geçerliği, iç tutarlık kat sayısı, doğrulayıcı faktör analizi ve test tekrar test değerlerinin sonuçlarına göre geçerli ve güvenilir bir ölçme aracı olarak kullanılabileceği rapor edilmiştir (Taştepe ve Akyol, 2019). Özel eğitim okul öncesi öğrencilerinin motor yeterliklerinin değerlendirildiği bir çalışmada, kaba, ince ve toplam motor bölümlerinde yetersiz durumların ortaya çıkışı motor gelişimin gecikmiş bir durum olduğunu doğrulamıştır (Riga, Misirli, ve Komessariou, 2020). PDMS-2'de ince motor ölçeğinin geçerlik ve güvenirliğinin yapıldığı bir çalışmada test tekrar test güvenirliği, uygulayıcılar arası güvenirlik ve iç tutarlık kat sayısı çok iyi derecede bulunmuş ve ince motor ölçek bölümünün geçerli ve güvenilir olduğu rapor edilmiştir. Buna rağmen çalışmanın popülasyonundaki ince motor becerilerde sorun yaşayan çocukların sadece \%39'unun PDMS-2 ince motor bölümüne göre sorunları bulunmuştur. Sonuç olarak bu bulgu "çalışmanın popülasyonu için yeterli hassasiyeti göstermemiştir" şeklinde söylenebilir (Van Hartingsveldt, Cup, ve Oostendorp, 2005). 12-48 aylık Portekizli çocuklarla yapılan bir çalışmada ince ve kaba motor becerileri değerlendirmek için uyumlu ve geçerli bir araç olduğu bulunmuştur (Rebelo ve diğ.,, 2020).

Movement ABC-2 Henderson, Sugden ve Barnett (2007) tarafından günlük yaşamdaki motor bozuklukları tanımlama amacıyla geliştirilmiştir. Movement ABC-2'nin yapısal geçerliği içerisinde üç ayrı yaş gurubunda faktör yapısını karşılaştırmak için yapılan bir çalışmada faktör yapısında yaşla birlikte motor becerilerdeki farklılaşmaya doğru bir değişiklik olduğu sonucuna varılmıştır (Schulz ve diğ.,, 2011). Movement ABC-2'nin gelişimsel koordinasyon bozukluğu olan çocukların motor değerlendirmesinde 'altın standart' olarak görülüp görülmediği konusunda yapılan bir çalışmada testin kullanışı ve uygulanabilir olduğu bulunmuştur. Fakat buna rağmen altın standart olarak tanımlanmaması ve eksikliklerinin göz ardı edilmemesi gerektiği çocukların motor yeterliğine dair net bir görüş sağlama becerisinin sorgulanabilir olması gerektiği belirtilmiştir (Venetsanou ve diğ.,, 2011). Okul öncesi çocukların hareket eksikliğinde kız çocukları ile erkek çocukları arasındaki farka bakılan bir çalışmada erkeklerin kızlardan ip atlama testinde daha iyi performans gösterdiğini belirten istatistiksel olarak cinsiyete dayalı anlamlı bir fark bulunmuştur. Bulgular okul öncesi çocuklarda yüksek oranda hareket güçlügü olduğunu göstermektedir (Jelovcan ve Zurc, 2015). Çin'de 3-10 yaş arası çocuklarda Birleşik Krallık normlarıyla yapılan karşılaştırmada Çinli çocukların el becerisi ve denge görevlerinde Birleşik Krallıktaki akranlarına kıyasla genel olarak daha iyi olduğu ortaya çıkmıştır. Birleşik Krallıktaki çocuklar ise yakalama ve nişan alma görevlerinde daha iyi oldukları sonucu belirtilmiştir (Ke ve diğ.,, 2020). 
KTK Kiphard ve Schilling (2007) tarafından genel dinamik denge becerisini değerlendirmek amacıyla geliştirilmiştir. Çocuk Beden Koordinasyon Testinin ortaokul grubu Türk çocukları için geçerlik ve güvenirliğinin yapıldığı bir çalışmada test tekrar test güvenirliği, ayırt edicilik indeksi, kapsam geçerliği indeksi, alt test korelasyon, eşzaman geçerliği değerlendirmelerine göre Türk ortaokul örneklemi açısından geçerli ve güvenirliği kabul edilebilir düzeyde olduğu belirtilmiştir (Özkara ve Kalkavan, 2018). Genç sporcularda KTK’nın kullanımına yönelik yapılan bir araştırmada analiz edilen literatür, KTK’nın farklı rekabet seviyelerindeki sporcular arasında ve farklı spor alanlarında başarılı bir şekilde ayrım yapabildiğini göstermiştir. Ayrıca, alt testler farklı rekabet seviyelerindeki sporcular için en büyük ayırt edici gücü sergilemiştir. Motor yeterliğin olgunlaşmadan etkilenmediği ve cinsiyetler veya oyun pozisyonları arasında farklılık göstermediği sonucu belirtilmiştir (O’BrienSmith ve diğ.,, 2019). Brezilyalı çocuklar ve gençler için KTK’nın faktör analizi, farkllılk ve faktör puanı bağlamında yapılan bir çalışmada KTK faktör yapısının toplam örneklem, cinsiyet ve yaş gruplarına göre model için yeterli olduğunu göstermiştir. Ancak çalışmanın sonuçları cinsiyet ve yaş grupları arasındaki farklılığı doğrulamamıştır. Alt testlerin ham puanlarının toplamının KTK'da faktör puan yöntemi olarak kullanılabileceği bulunmuş ve Brezilyalı çocukların-gençlerin motor yeterliğini ölçmek için geçerli bir araç olduğu sonucu belirtilmiştir (Moreira ve diğ.,, 2019). Hareketli müzik etkinliklerinin anasınıfı çocuklarında beden koordinasyonu gelişimine etkisinin incelendiği bir çalışmada deney ve kontrol grubunda yer alan çocukların Çocuk Beden Koordinasyon Testi (KTK) son test puanları arasında anlamlı bir farklılık bulunmuştur (Beyazit, 2012).

Büyük Kas Becerilerini Ölçme Testi (BÜKBÖT) Tepeli (2007) tarafından büyük kas becerilerini ölçmek amacıyla TGMD-2 'den uyarlanarak geliştirilmiştir. Montessori yönteminin anaokulu çocuklarının büyük kas becerilerine etkisinin incelendiği bir çalışmada deneme ve kontrol grubu çocuklarının BÜKBÖT son test puanları karşılaştırıldığında deneme grubu lehine anlamlı bir farklılık bulunmuş fakat deneme grubu çocuklarının BÜKBÖT son test ve izleme testi puan ortalamaları karşılaştırıldığında anlamlı bir farklılaşma olmadığı belirtilmiştir (Selçuk, 2016). Oyun ve hareket temelli kaba motor becerileri eğitim programlarının 4-5 yaş çocuklarının kaba motor becerileri üzerindeki etkisinin incelendiği bir çalışmada Oyuna ve Harekete Dayalı Büyük Kas Beceri Eğitimi Programlarına ilişkin uygulamaların 4-5 yaş arası çocukları olumlu yönde geliştirmiştir. Ancak bu yaş grubunda Oyuna Dayalı Büyük Kas Beceri Eğitimi Programının çocuklar üzerinde daha etkili olduğu sonucu belirtilmiştir (Tepeli, Koçak, ve Gül, 2014). 6-7 yaş grubu erkek öğrencilerin sosyo-ekonomik düzeyleri ile temel motor becerileri arasındaki farkın incelendiği bir çalışmada, öğrencilerin sosyo-ekonomik düzeyleri arttıkça büyük kas beceri ve alt beceri puanlarında da artış meydana geldiği tespit edilmiştir (Avşar, İbiş, ve Aktuğ, 2017). Zihinsel yetersizliği olan erkek ve kız çocuklarının fiziksel özellikleri ile yer değiştirme ve obje kontrol becerilerinin karşılaştırıldığı bir çalışmada, erkek ve kızlar arasında yaş, boy uzunluğu, vücut ağırlığı ve beden kütle indeksi bakımından anlamlı bir farklılığın olmadığı bulunmuştur. Sürat, sekme, atlama, yana kayma gibi yer değiştirme becerilerinde erkek ve kız çocuklar arasında anlamlı farklılık belirtilmemiştir. Nesne kontrol becerileri bakımından çift el sopa ile topa vuruş, yakalama ve temel yüksek atış becerileri erkek ve kız çocuklar arasında farklı bulunmazken sadece ayak ile şut becerisinde istatistiksel olarak anlamlı fark gözlenmiştir (Gülgösteren ve Ziyagil, 2019). 
Çalışmada incelediğimiz motor gelişim değerlendirme testlerinin temel amacı erken çocukluk döneminde ve okul çağında olan çocukların motor gelişimini bulundukları yaş dönemi içerisinde değerlendirmek ve çocukların gelişimi hakkında fikir vermektir. Motor gelişimin değerlendirilmesi, bulundukları yaş dönemine ait motor gelişimi göstermeyen çocukların eksikliklerinin belirlenmesi ve onların bu eksikliklerinin giderilmesi için de ayrı bir önem taşır. Bununla birlikte çocukların hareket performanslarını geliştirmeye ve iyileştirmeye yönelik hareket eğitimi programlarının hazırlanabilmesi için çocukların motor gelişim düzeyinin bilinmesi için bu veriler temel oluşturacaktır.

Sonuç olarak çocukların motor gelişiminin doğru ölçme araçları ile değerlendirilmesi, eğitimcilere ve ailelere çocukların gelişimi hakkında sağlıklı bir değerlendirme yapma olanağı sağlayacaktır.

\section{KAYNAKÇA}

Avşar, S., İbiş, S., ve Aktuğ, Z. B. (2017). 6-7 Yaş Grubu Erkek Öğrencilerin Sosyo Ekonomik Düzeyleri İle Temel Motor Beceriler Arasındaki Farkın İncelenmesi. Spor ve Performans Araştırmaları Dergisi, 8(2), $145-$ 153. DOI: $10.17155 /$ omuspd.322786.

Barnett, A. and Peters, J. (2004). Motor Proficiency Assessment Batteries In: Developmental Motor Disorders: A Neuropsychological Perspective Eds: Dewey and Tupper. New-York: Guilford.

Berk, L. (2003). Child Development 6. Edition. Boston: Allyn ve Bacon.

Beyazit, H. (2012). Hareketli Müzik Etkinliklerinin Anasınıfı Çocuklarında Beden Koordinasyon Gelişimine Etkisi. Yükseklisans Tezi. Marmara Üniversitesi, Eğitim Bilimleri Enstitüsü, İstanbul.

Boz, M., ve Güngör Aytar, A. (2012). Büyük Kas Motor Gelişim-2 (TGMD-2) Testinin Türk Çocuklarına Uyarlama Çalışması. Akdeniz Eğitim Araştırmaları Dergisi, 6(12), 17-24.

Brian, A., Bardid, F., Barnett, L. M., Deconinck, F. J. A., Lenoir, M., ve Goodway, J. D. (2018). Actual and Perceived Motor Competence Levels of Belgian and United States Preschool Children. Journal of Motor Learning and Development, 6(2), 320-336. DOI: 10.1123/jmld.2016-0071.

Brown, T. (2019). Structural Validity of the Bruininks-Oseretsky Test of Motor Proficiency-Second Edition (BOT-2) Subscales and Composite Scales. Journal of Occupational Therapy, Schools, and Early Intervention, 12(3), 323-353. DOI: 10.1080/19411.243.2019.1590755.

Bruininks, V. L., ve Bruininks, R. H. (1977). Motor Proficiency of Learning Disabled and Nondisabled Students. Perceptual and Motor Skills, 44, 1131-1137. DOI: 10.2466/pms.1977.44.3c.1131.

Bruininks, RH. (2005). Bruininks-Oseretsky Test of Motor Proficiency. MN: AGS Publishing Circle Pines.

Bruininks, RH., Oseretsky, BD.(2010). Bruininks-Oseretsky Test of Motor Proficiency, Second Edition Brief form. Bloomington: PsychCorp.

Burns, N., \& Grove, S. K. (2009). The Practice of Nursing Research: Appraisal, Synthesis, and Generation of Evidence. (6th ed., pp. 90-119, 598-610). USA: Saunders.

Burton, A.W. \& Miller, D.E. (1998) Movement Skill Assessment Champaign, IL: Human Kinetics.

Chow, S., Barnett, A.L. and Henderson, S.E. (2001) The Movement Assessment Battery for Children: A Comparison of 4-Year-Old to 6-Year-Old Children from Hong Kong and the United States. American Journal of Occupational Therapy, 55, 55-61.

Chow, S., Hsu, Y., Henderson, S.E., Barnett, A. and Kai, Lo. S. (2006) The Movement ABC: a Cross-Cultural Comparison of Pre-School Children from Hong Kong, Taiwan, and the USA. Adapted Physical Activity Quarterly, 23, 31-48. 
Cools, W., Martelaer, K. De, Samaey, C., ve Andries, C. (2009). Movement Skill Assessmen of Typically Developing Preschool Children: A Review of Seven Movement Skill Assessment Tools. Journal of Sports Science and Medicine, 8(2), 154-168.

Davies, M. (2003). Movement and Dance in Early Childhood, Second edition. London: Paul Chapman Publishing.

Deitz, J. C., Kartin, D., ve Kopp, K. (2007). Review of the Bruininks-Oseretsky Test of Motor Proficiency, Second Edition (BOT-2). Physical \& Occupational Therapy in Pediatrics, 27(4), 87-102. DOI: 10.1080/ J006v27n04_06.

Folio, M. R., Fewell, R. R. (1983). Peabody Developmental Motor Scales, Revised. Allen, TX: DLM Teaching Resources.

Folio, M R., Fewell, R.R. (2000). The Peabody Developmental Motor Scales (2nd Ed.). Austin, Tx: PRO-ED.

Fransen, J., D’Hondt, E., Bourgois, J., Vaeyens, R., Philippaerts, R. M. ve Lenoir, M. (2014). Motor Competence Assessment in Children: Convergent and Discriminant Validity Between the BOT-2 Short Form and KTK Testing Batteries. Research in Developmental Disabilities, 35(6), 1375-1383. DOI: 10.1016/j. ridd.2014.03.011.

Gallahue, D., Ozmun, J., ve Goodway, J. (2006). Understanding Motor Development: Infants, Children, Adolescents, Adults (Seventh). New York: The McGraw Hill Companies.

Gerrish, K., \& Lacey, A. (2010). The Research Process in Nursing. (6th ed., pp. 79-92, 188-198, 284-302). London: Wiley-Blackwell.

Goodway, J. D., Robinson, L. E., ve Crowe, H. (2010). Gender Differences in Fundamental Motor Skill Development in Disadvantaged Preschoolers from Two Geographical Regions. Research Quarterly for Exercise and Sport, 81(1), 17-24. DOI: 10.1080/02701.367.2010.10599624.

Gülgösteren, E., ve Ziyagil, M. A. (2019). Zihinsel Engelli Erkek ve Kız Çocukların Fiziksel Özellikleri ile Yer Değiştirme ve Obje Kontrol Becerilerinin Karşılaştırılması. Gönülateş S. (Ed.) 2.Uluslararası Herkes İçin Spor ve Wellness Kongresi Tam Metin Kitabı içinde (s.721-725). Mersin: Mersin Üniversitesi.

Hardman, C.M, Wanderley Júnior, Rildo de Souza, Oliveira, E. S. A. ve Barros, M.V. G. (2017). Relationship Between Physical Activity and BMI with Level of Motor Coordination Performance in School Children. Revista Brasileira de Cineantropometria Desempenho Humano, 19(1), 50-61. DOI: 10.5007/1980-0037.2017v19n1p50.

Henderson, S.E. and Sugden, D.A. (1992). Movement Assessment Battery for Children. England: Sidcup.

Henderson, S. E., Sugden, D. A., \& Barnett, A. L. (2007). Movement Assessment Battery for Children-2 Second Edition (Movement ABC-2). London, UK: The Psychological Corporation.

Jelovcan, G., ve Zurc, J. (2016). Preschool Childrens Results in Movement Abc Tests Differences Between Girls and Boys in Movement Defict. Annales Kinesiologiae, 7(1), 3-19.

Karaçam, Z. (2013). Sistematik Derleme Metodolojisi: Sistematik Derleme Hazırlamak İçin Bir Rehber. Dokuz Eylül Üniversitesi Hemşirelik Fakültesi Elektronik Dergisi, 6(1), 26-33.

Karakaş, G. (2018). Hafif Düzeyde Zihinsel Engelli Çocuklara Uygulanan Serbest Zaman Aktivitelerinin Fiziksel Uygunluk ve Motor Gelişimleri Üzerine Etkisi. Doktora Tezi. Sakarya Üniversitesi, Eğitim Bilimleri Enstitüsü, Sakarya.

Karambe, P., Dhote, S. N., ve Palekar, T. J. (2017). Assessment of Bilateral Coordination Using Bruininks Oseretsky Test of Motor Proficiency 2 Edition (BOT-2) in 5 to 15 Years School Going Children. International Journal of Physiotherapy and Research, 5(3), 2026-2030. DOI: 10.16965/ijpr.2017.129.

Ke, L., Du, W., Wang, Y., Duan, W., Hua, J., ve Barnett, A. L. (2020). The Movement ABC-2 Test in China: Comparison with UK Norms for 3-10 Year Olds. Research in Developmental Disabilities, 105(3), 1-11. DOI: 10.1016/j.ridd.2020.103742. 
Kerkez, F.İ. (2013) Türkiye'de Çocuklarda Motor Gelişimin Değerlendirilmesinde TGDM-2 Uygulamalarına Bir Bakış. Hacettepe Spor Bilimleri Dergisi, 24(3), 245-256.

Kılıç, Z., Uyanık Balat, G., ve Çağlak Sarı, S. (2017). CHAMPS Motor Beceriler Protokolünün ( CMSP ) 4 ve 5 Yaş Çocuklarına Yönelik Türkçeye Uyarlama Çalışması. Eğitim Kuram ve Uygulama Araştırmaları Dergisi, 3(3), 129-142.

Kiphard, E. ve Schilling, F. (2000). Körperkoordinationstest für Kinder. Weinheim: Beltz Test.

Kiphard, E. J., Schilling, F. (2007). Körperkoordinationstest für Kinder 2. Überarbeitete und Ergänzte Auflage: Beltz Test.

Köse, B. (2018). Bruininks - Oseretsky Motor Yeterlik Testi 2 Kısa Formunun Türkçe Uyarlaması Ve Özgül Öğrenme Güçlüğü Olan Çocuklarda Geçerlilik ve Güvenilirliği.Yükseklisans Tezi, Hacettepe Üniversitesi Sağlık Bilimleri Enstitüsü, Ankara.

Livonen,S., Saakslahti, A., Laukkanen A.(2016). A Review of Studies Using the Körperkoordinationstest für Kinder. European Federation of Adapted Physical Activity, 8(2), 18- 36. DOI: 10.5507/euj.2015.006.

Logan, S. W., Robinson, L. E., Rudisill, M. E., Wadsworth, D. D., ve Morera, M. (2012). The Comparison of School Age Children's Performance on Two Motor Assessments: The Test of Gross Motor Development and the Movement Assessment Battery for Children. Physical Education and Sport Pedagogy, 12(1), 4859. DOI: $10.1080 / 17408.989 .2012 .726979$.

Lopes, V. P., Saraiva, L., ve Rodrigues, L. P. (2018). Reliability and Construct Validity of the Test of Gross Motor Development-2 in Portuguese Children. International Journal of Sport and Exercise Psychology, 16(3), 250-260. DOI: 10.1080/1612197X.2016.122.6923.

Moreira, J. P. A., Lopes, M. C., Miranda-Júnior, M. V., Valentini, N. C., Lage, G. M., ve Albuquerque, M. R. (2019). Körperkoordinationstest Für Kinder (KTK) for Brazilian Children and Adolescents Factor Analysis, Invariance and Factor Score. Frontiers in Psychology, 10(2524), 1-12. DOI: 10.3389/fpsyg.2019.02524.

Moula, P., \& Goodman M. (2009). Nursing Research. (pp. 111-149, 247-261). London: SAGE Publication Ltd.

Mülazımoğlu Ballı, Ö., ve Gürsoy, F. (2012). Bruininks-Oseretsky Motor Yeterlik Testinin Beş-Altı Yaş Grubu Türk Çocuklar İçin Geçerlik ve Güvenirlik Çalışması. Spor Bilimleri Dergisi, 23(3), 104-118.

O’Brien-Smith, J., Tribolet, R., Smith, M. R., Bennett, K. J. M., Fransen, J., Pion, J., ve Lenoir, M. (2019). The Use of the Körperkoordinationstest Für Kinder in the Talent Pathway in Youth Athletes: A systematic Review. Journal of Science and Medicine in Sport, 22(9), 1021-1029. DOI: 10.1016/j.jsams.2019.05.014.

Özkara, A. B., ve Kalkavan, A. (2018). Çocuk Beden Koordinasyon Testinin Ortaokul Grubu Türk Çocukları İçin Geçerlik ve Güvenirlik Çalışması. Spormetre, 16(4), 1-11. DOI: 10.1501/Sporm_000.000.0389.

Petermann, F. (Hrsg.). (2008). Movement Assessment Battery for Children-2 (Movement ABC-2). Frankfurt: Pearson PLC.

Portney L. (2000) Correlation. Foundations of Clinical Research.

Preeti, G., Anil, V. N., Sara, A. B., Shivani, D., M, V., ve Jaideep, A. (2019). Assessment of Fine Manual Control Using Bruininks Oseretsky Test of Motor Proficiency 2 nd Edition (BOT-2) in School Going Overweight and Obese Children Aged 7 to12 Years, International Journal of Basic and Applied Research, 9(4), 544553.

Rebelo, M., Serrano, J., Duarte Mendes, P., Paulo, R., ve Marinho, D. A. (2020). Adaptation and Validation of the Portuguese Peabody Developmental Motor Scales-2 Edition a Study With Children Aged 12 to 48 Months. Research Square, 1-17. DOI: 10.21203/rs.3.rs-66818/v1.

Riga, V., Misirli, A., ve Komessariou, A. (2020). Assessment of Motor Development of Preschool Children With Special Education Needs. European Journal of Physical Education and Sport Science, 6(7), 17-34. DOI: 10.46827/ejpe.v6i7.3303. 
Rosenbaum, P., Missiuna, C. and Johnson, K. (2004) Longitudinal Assessment of Motor Development in Epidemiologic Research for the National Children's Study. Report for the NCS by Battelle Memorial Institute.

Schmidt, \& Lee, T. (1988). Motor Control and Learning. Leeds: Human Kinetics.

Soppelsa R. and Albaret J.-M. (2004). Manuel de la Batterie d'Evaluation du Mouvement Chez l'Enfant. Paris: ECPA.

Schulz, J., Henderson, S. E., Sugden, D. A., ve Barnett, A. L. (2011). Structural Validity of the Movement ABC-2 test Factor Structure Comparisons Across Three Age Groups. Research in Developmental Disabilities, 32(4), 1361-1369. DOI: 10.1016/j.ridd.2011.01.032.

Selçuk, K. S. (2016). Montessori Yönteminin Anaokulu Çocuklarinin Büyük Kas Becerilerine Etkisinin İncelenmesi. Yükseklisans Tezi. Necmettin Erbakan Üniversitesi, Eğitim Bilimleri Enstitüsü, Konya.

Simons, J. and Van Hombeeck, C. (2003). Toepasbaarheid van de Test of Gross Motor Development 2nd ed. Kinevaria, 39(4), 16-21.

Simons, J. (2004) Introductie Tot de Psychomotoriek. Garant, Antwer - Pen-Appeldoorn.

Ulrich, D. A. (2000). Test of Gross Motor Development 2: Examiner's Manual (2nd ed.). Austin, Tx: Pro-Ed.

Taştepe, T. (2018). 36 - 47 Aylık Çocuklara ve Annelere Uygulanan Motor Gelişim Destek Programının Çocukların Motor Gelişimine Etkisinin İncelenmesi. Doktora Tezi. Ankara Üniversitesi, Sağlık Bilimleri Enstitüsü, Ankara.

Taştepe, T., ve Köksal Akyol, A. (2019). 36-47 Aylık Çocuklarda Peabody Motor Gelişim Ölçeği-2’nin Uyarlama Çalışması ve Motor Gelişimin İncelenmesi. Milli Eğitim, 48(223), 61-82.

Tepeli, K. (2007). Büyük Kas Becerilerini Ölçme Testi (BüKBÖT)'nin Türkiye Standardizasyonu. Doktora Tezi. Selçuk Üniversitesi Sosyal Bilimler Enstitüsü, Konya.

Tepeli, K., Koçak, N., ve Gül, O. (2014). The Comparison of the Effect of Game and Motion Based Gross Motor Skills Training Programmes on the 4-5 Year Old Childrens Gross Motor Skills. Turkish Journal of Sport and Exercise, 16(2), 9-14. DOI: 10.15314/TJSE.201428099.

Tieman, B. L., Palisano, R. J. ve Sutlive, A. C. (2005). Assessment of Motor Development and Function in Preschool Children. Mental Retardation and Developmental Disabilities Research Reviews, 11(3), 189196. DOI: $10.1002 / \operatorname{mrdd} .20074$.

Topkaya, İ. (2015). Hareket Beden Eğitimi ve Spor Öğretiminde Öğrenme ve Öğretimin Temelleri, 4.Baskı. Ankara.

Valentini, N. C. (2012). Validity and Reliability of the TGMD-2 for Brazilian Children. Journal of Motor Behavior, 44(4), 275-280. DOI: 10.1080/00222.895.2012.700967.

Vallaey, M. and Vandroemme, G. (2001) Psychomotoriek Bij Kinderen. Leuven: Acco.

Van Hartingsveldt, M. J., Cup, E. H. C., ve Oostendorp, R. A. B. (2005). Reliability and Validity of the Fine Motor Scale of the Peabody Developmental Motor Scales-2. Occupational Therapy International, 12(1), 1-13. DOI: 10.1002/oti.11.

Venetsanou, F., Kambas, A., Ellinoudis, T., Fatouros, I., Giannakidou, D., ve Kourtessis, T. (2011). Can the Movement Assessment Battery for Children Test be the "gold standard" for the Motor Assessment of Children with Developmental Coordination Disorder? Research in Developmental Disabilities, 32(1), 1-10. DOI: 10.1016/j.ridd.2010.09.006.

Wiart, L., Darrah, J. (2001). Review of four tests of gross motor development. Developmental Medicine and Child Neurology, 43, 279-285. DOI: 10.1111/j.1469-8749.2001.tb00204.x

Williams, H. G., Pfeiffer, K. A., O’Neill, J. R., Dowda, M., McIver, K. L., Brown, W. H., ve Pate, R. R. (2008). Motor Skill Performance and Physical Activity in Preschool Children. Obesity, 16(6), 1421-1426. DOI: 10.1038/oby.2008.214. 
Williams, H. G., Pfeiffer, K. A., Dowda, M., Jeter, C. Jones, S. ve Pate, R. (2009). A Field Based Testing Protocol for Assessing Gross Motor Skills in Preschool Children: The Champs Motor Skills Ptorocol (cmsp). MeasurementPysicalEducationandExerciseScience,13(3),151-165.DOI:10.1080/109.136.70903048036.

Yoon, D, Scott, K. ve Hill, M. (2006). Review of Three Tests of Motor Proficiency in Children. Perceptual \& Motor Skills, 102, 543 - 551. DOI: 10.2466/pms.102.2.543-551. 